\title{
Sexual dimorphism of kisspeptin and neurokinin B immunoreactive neurons in the infundibular nucleus of aged men and women
}

\section{Erik Hrabovszky ${ }^{1}{ }^{*}$, Csilla S. Molnár ${ }^{1}$, Máté T. Sipos ${ }^{1}$, Barbara Vida ${ }^{1}$, Philippe Ciofi ${ }^{2}$, Beáta A. Borsay ${ }^{3}$, László Sarkadi ${ }^{4}$, László Herczeg ${ }^{3}$, Stephen R. Bloom ${ }^{4}$, Mohammad A. Ghatei $^{4}$, Waljit S. Dhillo ${ }^{4}$, Imre Kalló $^{1,5}$ and Zsolt Liposits ${ }^{1,5}$}

\author{
${ }^{1}$ Laboratory of Endocrine Neurobiology, Institute of Experimental Medicine, Hungarian Academy of Sciences, Budapest, Hungary \\ 2 INSERM U862, Neurocentre Magendie, Bordeaux, France \\ ${ }^{3}$ Department of Forensic Medicine, University of Debrecen, Debrecen, Hungary \\ ${ }^{4}$ Department of Investigative Medicine, Hammersmith Hospital, Imperial College London, London, UK \\ ${ }^{5}$ Department of Neuroscience, Pázmány Péter Catholic University, Budapest, Hungary
}

\section{Edited by:}

Henryk Urbanski, Oregon National

Primate Research Center, USA

\section{Reviewed by:}

A. Kemal Topaloglu, Cukurova University Medicine, Turkey

Johnny Deladoey, University of

Montreal, Canada

*Correspondence:

Erik Hrabovszky, Laboratory of Endocrine Neurobiology, Institute of

Experimental Medicine, Hungarian Academy of Sciences, 43 Szigony Street, Budapest 1083, Hungary. e-mail: hrabovszky@koki.hu

${ }^{t}$ The authors dedicate this article to the memory of our colleague Dr. László Sarkadi who has recently passed away.
The secretory output of gonadotropin-releasing hormone $(\mathrm{GnRH})$ neurons is critically influenced by peptidergic neurons synthesizing kisspeptins (KP) and neurokinin $B(N K B)$ in the hypothalamic infundibular nucleus (Inf). These cells mediate negative feedback effects of sex steroids on the reproductive axis. While negative feedback is lost in postmenopausal women, it is partly preserved by the sustained testosterone secretion in aged men. We hypothesized that the different reproductive physiology of aged men and women is reflected in morphological differences of KP and NKB neurons. This sexual dimorphism was studied with immunohistochemistry in hypothalamic sections of aged human male ( $\geq 50$ years) and female ( $>55$ years) subjects. KP and NKB cell bodies of the Inf were larger in females. The number of KP cell bodies, the density of KP fibers, and the incidence of their contacts on $\mathrm{GnRH}$ neurons were much higher in aged women compared with men. The number of NKB cell bodies was only slightly higher in women and there was no sexual dimorphism in the regional density of NKB fibers and the incidence of their appositions onto $\mathrm{GnRH}$ cells. The incidences of NKB cell bodies, fibers, and appositions onto $\mathrm{GnRH}$ neurons exceeded several-fold those of KP-IR elements in men. More NKB than KP inputs to $\mathrm{GnRH}$ cells were also present in women. Immunofluorescent studies identified only partial overlap between KP and NKB axons. KP and NKB were colocalized in higher percentages of afferents to $\mathrm{GnRH}$ neurons in women compared with men. Most of these sex differences might be explained with the lack of estrogen negative feedback in aged women, whereas testosterone can continue to suppress KP, and to a lesser extent, NKB synthesis in men. Overall, sex differences in reproductive physiology of aged humans were reflected in the dramatic sexual dimorphism of the KP system, with significantly higher incidences of KP-IR neurons, fibers and inputs to $\mathrm{GnRH}$ neurons in aged females vs. males.

Keywords: immunohistochemistry, infundibulum, reproduction, gonadotropin-releasing hormone

\section{INTRODUCTION}

Neurons synthesizing gonadotropin-releasing hormone-I (GnRH) represent the final common pathway of the hypothalamus in the neuroendocrine regulation of reproduction. The pulsatile pattern of GnRH secretion into the hypophysial portal circulation is shaped by a sex steroid-sensitive neuronal circuitry that acts upstream from GnRH cells (Christian and Moenter, 2010). In both males (Tilbrook and Clarke, 2001) and females (Moenter et al., 2009), gonadal steroid hormones exert homeostatic negative feedback on GnRH release via this upstream circuitry. In females, elevated estradiol in the late follicular phase of the reproductive cycle causes a switch from negative to positive feedback to induce a surge of GnRH from the hypothalamus. The subsequent surge of luteinizing hormone from the adenohypophysis triggers ovulation (Christian and Moenter, 2010).

Much research effort over the past decades has been invested in the identification of the neuronal circuitry that mediates the negative and positive feedback effects of gonadal steroid hormones to the GnRH neuronal system. Hypothalamic neurons synthesizing kisspeptins and NKB are recently recognized key players of this neuronal network. Loss-of-function mutations of the genes encoding kisspeptin receptor (KISS1R; de Roux et al., 2003; Seminara et al., 2003; Semple et al., 2005), NKB (Topaloglu et al., 2009), or the receptor for NKB (NK3; Guran et al., 2009; Topaloglu et al., 2009) cause hypogonadotropic hypogonadism in the human. Kisspeptins regulate reproduction via direct stimulatory actions on GnRH neurons. Accordingly, GnRH 
neurons receive kisspeptin-immunoreactive (IR) afferent contacts (Kinoshita et al., 2005; Clarkson and Herbison, 2006; Ramaswamy et al., 2008; Smith et al., 2008; Hrabovszky et al., 2010), express KISS1R mRNA (Irwig et al., 2004; Han et al., 2005; Messager et al., 2005) and respond to kisspeptins with depolarization (Han et al., 2005; Dumalska et al., 2008; Pielecka-Fortuna et al., 2008) and cFos expression (Irwig et al., 2004; Matsui et al., 2004; Kauffman et al., 2007). Similarly to kisspeptins, NKB acts upstream from the GnRH neuron. Neurokinin B-IR axons form frequent intranuclear contacts with other NKB-IR neurons that express the NKB receptor (NK3) in the arcuate nucleus (ARC; Burke et al., 2006; Navarro et al., 2009; Amstalden et al., 2010). In addition, the possibility exists that NKB influences GnRH secretion from the hypothalamic median eminence where GnRH-IR axons are apposed to NKB-IR axons (Krajewski et al., 2005; Ciofi et al., 2006) and express NK3 immunoreactivity (Krajewski et al., 2005) in the rat.

As reviewed recently (Lehman et al., 2010b), kisspeptin synthesizing neurons in various mammalian species have been localized to two major anatomical sites, the preoptic region and the ARC. Neurokinin B neurons have a wider distribution. A role in reproduction is likely attributable to NKB neurons of the ARC which also synthesize kisspeptins and dynorphins in several species (Goodman et al., 2007; Navarro et al., 2009; Cheng et al., 2010).

The kisspeptin cell population of the preoptic region exhibits conspicuous anatomical variations among species. In laboratory rodents, they form a compact nucleus in the rostral periventricular area of the third ventricle (RP3V; Gottsch et al., 2004; Smith et al., 2005a, 2006b; also referred to as kisspeptin neurons of the anteroventral periventricular nucleus; AVPV) and exhibit a robust sexual dimorphism. They occur in higher numbers (Clarkson and Herbison, 2006; Adachi et al., 2007; Kauffman et al., 2007; Ansel et al., 2010) and provide input to a higher percentage of GnRH neurons (Clarkson and Herbison, 2006) in females compared with males. There is strong evidence suggesting that in rodents, the kisspeptin cell population of the RP3V is critically involved in positive estrogen feedback to GnRH neurons (Adachi et al., 2007; Herbison, 2008). Kisspeptin synthesizing neurons are more scattered and occur in lower numbers in the preoptic region of the sheep (Franceschini et al., 2006; Goodman et al., 2007), the monkey (Smith et al., 2010), and the human (Hrabovszky et al., 2010). The issue of whether preoptic kisspeptin neurons of these species are functionally homologous to kisspeptin neurons of the rodent RP3V is debated, given that positive estrogen feedback in sheep (Caraty et al., 1998) and primates (Krey et al., 1975; Hess et al., 1977; Knobil, 1980) is thought to take place in the ARC (infundibular nucleus; Inf, in humans).

The second kisspeptin synthesizing cell group can be consistently detected within the ARC in all animal species studied (Gottsch et al., 2004; Irwig et al., 2004; Han et al., 2005; Kinoshita et al., 2005; Shahab et al., 2005; Smith et al., 2005a, 2007, 2008, 2009, 2010; Clarkson and Herbison, 2006; Estrada et al., 2006; Franceschini et al., 2006; Revel et al., 2006; Adachi et al., 2007; Goodman et al., 2007; Greives et al., 2007; Mason et al., 2007; Rometo et al., 2007; Decourt et al., 2008; Ramaswamy et al., 2008, 2010; Clarkson et al., 2009; Kauffman, 2009; Magee et al., 2009; Ohkura et al., 2009; Takase et al., 2009; Ansel et al., 2010; Cheng et al., 2010; Desroziers et al., 2010; Wakabayashi et al., 2010) and in the analogous Inf of the human (Rometo et al., 2007; Hrabovszky et al., 2010). Unlike the preoptic kisspeptin cell population, these kisspeptin neurons also synthesize NKB in sheep (Goodman et al., 2007; Cheng et al., 2010), goat (Wakabayashi et al., 2010), mice (Navarro et al., 2009), monkey (Ramaswamy et al., 2010), and human (Hrabovszky et al., 2010). The recently introduced terminology of KNDy neurons (Cheng et al., 2010) refers to the co-synthesis of dynorphins by the majority of these kisspeptin/NKB cells at least in the sheep (Goodman et al., 2007; Cheng et al., 2010), the goat (Wakabayashi et al., 2010), the mouse (Navarro et al., 2009), and the rat (Burke et al., 2006). Evidence from studies of sheep suggests that KNDy neurons of the ARC play an important role in conveying the negative feedback effects of sexual steroids onto GnRH neurons (Smith et al., 2007), and possibly, also the positive feedback effects of estrogens (Lehman et al., 2010a) in this species. Thus, KNDy neurons appear to constitute an important component of the $\mathrm{GnRH}$ pulse generator (Navarro et al., 2009; Wakabayashi et al., 2010).

The sex-specific spatial and temporal patterns of hypothalamic kisspeptin expression strongly depend on the activational effects of sexual steroid hormones. Large subsets of kisspeptin neurons in both the preoptic region and the ARC contain receptors for estradiol, testosterone, and progesterone in various species (Smith et al., 2005a,b, 2006b, 2007; Franceschini et al., 2006; Adachi et al., 2007; Clarkson et al., 2008; Cheng et al., 2010). In rodents, androgens and estrogens upregulate kisspeptin expression in the RP3V (Smith et al., 2005a,b, 2006a; Adachi et al., 2007; Kauffman et al., 2007) at the site of positive estrogen feedback. In contrast, kisspeptin expression in the ARC/Inf is regulated negatively by sex steroid hormones in rodents and other species (Smith et al., 2005a,b, 2006a; Adachi et al., 2007; Kauffman et al., 2007; Kim et al., 2009; Eghlidi et al., 2010) and so is NKB expression at this site (Rance and Young, 1991; Abel et al., 1999; Danzer et al., 1999; Dellovade and Merchenthaler, 2004; Eghlidi et al., 2010).

The sex-dependent pattern of hypothalamic kisspeptin expression also depends on the organizational effects of testosterone exposure in males, in addition to the circulating levels of sex steroid hormones. There is a neonatally determined robust sexual dimorphism of the RP3V in adult rats (Kauffman et al., 2007) and mice (Clarkson and Herbison, 2006), with higher cell numbers in females compared with males. Prenatal testosterone exposure accounts for a similar sexual dimorphism of kisspeptin neurons in the preoptic area of the sheep (Cheng et al., 2010).

In contrast, no apparent organizational effects of the perinatal testosterone exposure have been observed on the abundance of kisspeptin neurons in the rodent ARC which contains similar kisspeptin cell numbers in intact males and in diestrous females, or in gonadectomized males and females receiving the same estrogen or testosterone regimen (Kauffman et al., 2007). No sex difference appears to exist in the number of NKB neurons either. However, in the rat a sexual dimorphism that develops under the organizational effects of sex steroids has been reported in the projection fields of NKB-IR axons (Ciofi et al., 2006). Unlike in rodents, the ARC of the female sheep contains higher NKB (Goubillon et al., 2000) and kisspeptin (Cheng et al., 2010) cell numbers, compared with males. Moreover, in our previous work we have also identified higher kisspeptin neuron and fiber densities in the Inf of women vs. men (Hrabovszky et al., 2010); it requires clarification to what 
extent this sexual dimorphism reflects the organizational effects of sex steroids during development or the difference in the adult hormonal status between men and women.

Reproductive aging is accompanied by sex-specific neuromorphological alterations of the Inf. While gonadal functions in aging men can be well-preserved throughout life (Araujo and Wittert, 2011), the negative feedback response of the reproductive axis to testosterone shows a declining trend (Veldhuis et al., 2010). This reduced feedback may be correlated with a mild neuronal hypertrophy in the Inf of aged men (Rance et al., 1993). Reproductive aging is more dramatic in postmenopausal women after the depletion of ovarian follicles, leading to the loss of circulating estrogen and causing the reduction of negative estrogen feedback (Rance, 2009). Comparison of histological samples from pre- and postmenopausal women revealed profound anatomical changes in the Inf where negative feedback is thought to take place (Rance, 2009). Accordingly, in situ hybridization studies identified the postmenopausal hypertrophy of neurons that express estrogen receptor alpha (Rance et al., 1990), substance P (Rance and Young, 1991), NKB (Rance and Young, 1991), kisspeptins (Rometo et al., 2007), and prodynorphin (Rometo and Rance, 2008). These morphometric alterations were also associated with increased NKB (Rance and Young, 1991) and kisspeptin (Rometo et al., 2007) and decreased prodynorphin mRNA expression (Rometo and Rance, 2008) at this site.

In the present study we address several immunohistochemical correlates of the functional differences that characterize the kisspeptin and NKB neuronal systems of the Inf in aged men and women. The comparative analysis of post mortem histological samples from intact human male and female subjects reveals sex differences that likely represent the combined organizational and activational effects of sex steroids. The following parameters will be analyzed and compared:

(i) Perikaryon size of kisspeptin-IR and preproNKB-IR neurons Previous morphometric studies established a robust postmenopausal hypertrophy of NKB (Rance and Young, 1991) and kisspeptin (Rometo et al., 2007) mRNA expressing neurons that were identified with in situ hybridization. A mild neuronal hypertrophy also occurs with aging in unidentified neurons of the Inf in men (Rance et al., 1993). Considering the negative feedback effect of the continued testosterone exposure, we predict smaller kisspeptin-IR and NKB-IR neuronal perikarya in aged men vs. women. In the present study, we measured and compared the profile area of kisspeptin-IR and NKB-IR neurons between aged male ( $\geq 50$ years) and postmenopausal female ( $\geq 55$ years) subjects.

(ii) Incidence of kisspeptin-IR and preproNKB-IR cell bodies in the Inf

A recent immunohistochemical study from our laboratory detected significantly more kisspeptin-IR cell bodies in the Inf of women vs. men of various ages (Hrabovszky et al., 2010). Here we repeated this study on histological samples derived from aged men and postmenopausal women. We extended the quantitative analysis to preproNKB-IR neurons that show a substantial overlap with kisspeptin-IR neurons in human females (Hrabovszky et al., 2010). (iii) Regional density of kisspeptin-IR and preproNKB-IR fibers Our previous immunohistochemical study also revealed more kisspeptin-IR axonal profiles in the Inf and other hypothalamic regions of women compared with men (Hrabovszky et al., 2010). Here we used computerized image analysis to compare the regional densities of kisspeptin-IR and preproNKB-IR fibers between aged men and women.

(iv) Frequency of kisspeptin-IR and preproNKB-IR appositions onto GnRH-IR neurons

A sexual dimorphism has been observed in the innervation pattern of GnRH neurons in mice, in that a higher percentage of rostral preoptic GnRH neurons receive kisspeptinIR appositions in females compared with males (Clarkson and Herbison, 2006). In our previous immunohistochemical study of human hypothalami we provided morphological indication that kisspeptin-IR axons communicate with GnRH-IR neurons via axo-somatic, axo-dendritic, and axo-axonal interactions (Hrabovszky et al., 2010). Here we addressed a sex difference in the incidences of axosomatic and axo-dendritic appositions of kisspeptin-IR and preproNKB-IR fibers onto GnRH-IR neurons of the Inf.

(v) Colocalization of kisspeptins and preproNKB-IR in afferents to GnRH-IR neurons

In a previous dual-immunofluorescent study we demonstrated a partial colocalization of kisspeptin and preproNKB immunoreactivities in female human subjects (Hrabovszky et al., 2010). The fraction of kisspeptin-IR axons with $\mathrm{NKB}$ signal (56\% in the Inf and $17 \%$ in the periventricular nucleus) and reversely, was surprisingly low, considering the good matches of kisspeptin, NKB, and dynorphin labeling in the ARC of the female sheep (Goodman et al., 2007) and mice (Navarro et al., 2009). Here we carried out triple-immunofluorescent studies coupled with confocal microscopy to determine whether kisspeptin and preproNKB immunoreactivities are colocalized in afferent contacts on GnRH neurons.

\section{MATERIALS AND METHODS HUMAN SUBJECTS}

Human hypothalamic tissue samples from nine male subjects above 50 years of age $(50,50,52,53,59,62,66,66,67$ years $)$ and from seven postmenopausal female subjects above 55 years of age $(57,57,58,63,64,69,70$ years) were obtained at autopsy from the Forensic Medicine Department of the University of Debrecen, with the permission of the Regional Committee of Science and Research Ethics (DEOEC RKEB/IKEB: 3183-2010). Selection criteria included sudden causes of death, lack of history of neurological and endocrine disorders and post mortem intervals between 12 and $48 \mathrm{~h}$.

\section{TISSUE PREPARATION FOR IMMUNOHISTOCHEMISTRY}

Following dissection, the hypothalamic tissue blocks were rinsed briefly with running tap water and then, immersion-fixed with $4 \%$ paraformaldehyde in $0.1 \mathrm{M}$ phosphate buffer saline (PBS; $\mathrm{pH}$ 7.4) for 7-14 days at $4^{\circ} \mathrm{C}$. Following fixation, the hypothalami were trimmed further to include the optic chiasma rostrally, the mammillary bodies caudally, and the anterior commissure dorsally 
(Hrabovszky et al., 2007, 2010). Sagittal cuts were made $2 \mathrm{~cm}$ lateral from midsagittal plane on both sides and then, the blocks were cut in halves and infiltrated with $20 \%$ sucrose for 5 days at $4^{\circ} \mathrm{C}$. The right hemihypothalami were placed in a freezing mold, surrounded with Jung tissue freezing medium (Leica Microsystems, Nussloch Gmbh, Germany; diluted 1:1 with $0.9 \%$ sodium chloride solution), snap-frozen on powdered dry ice, and sectioned serially at $30 \mu \mathrm{m}$ with a Leica SM 2000R freezing microtome (Leica Microsystems) parallel to the plane of the lamina terminalis. The sections were stored permanently in anti-freeze solution (30\% ethylene glycol; 25\% glycerol; $0.05 \mathrm{M}$ phosphate buffer; $\mathrm{pH} 7.4$ ) at $-20^{\circ} \mathrm{C}$.

\section{TISSUE PRETREATMENTS}

Prior to immunohistochemistry, the sections were rinsed in PBS and pretreated with a mixture of $0.5 \% \mathrm{H}_{2} \mathrm{O}_{2}$ and $0.2 \%$ Triton $\times-100$ for $30 \mathrm{~min}$. Then, antigen retrieval was carried out by using a $0.1 \mathrm{M}$ citrate buffer wash at $80^{\circ} \mathrm{C}$ for $30 \mathrm{~min}$. In dualimmunofluorescent experiments, the sections were also pretreated with Sudan black to reduce tissue autofluorescence from lipofuscin deposits, as described earlier (Mihaly et al., 2002; Hrabovszky et al., 2010).

\section{DETECTION OF KISSPEPTIN AND NEUROKININ B SYNTHESIZING NEURONS}

To detect kisspeptin immunoreactivity, every 24th hemihypothalamic section from the infundibular nucleus of each human individual was incubated in a sheep polyclonal antiserum (GQ2; 1:100,000) against human kisspeptin-54. This antiserum recognizes human kisspeptin-54, kisspeptin-14, and kisspeptin-10 and it shows virtually no cross-reactivity $(<0.01 \%)$ with other related human RF amide peptide, including prolactin releasing peptide, neuropeptide FF, neuropeptide AF, and RF amide-related peptides (RFRP1, RFRP2, RFRP3; Dhillo et al., 2005). The GQ2 antibodies were used successfully in previous immunohistochemical experiments to study the distribution of kisspeptin neurons and their connectivity to GnRH cells in the rhesus monkey (Ramaswamy et al., 2008) and the human (Hrabovszky et al., 2010). Incubation in the GQ2 primary antisera $\left(48 \mathrm{~h}\right.$ at $\left.4^{\circ} \mathrm{C}\right)$ was followed by biotinylated secondary antibodies (biotin-SP-antisheep IgG; Jackson ImmunoResearch Laboratories, West Grove, PA, USA; 1:500) and the ABC Elite reagent (Vector, Burlingame, CA, USA; 1:1000) for $60 \mathrm{~min}$ each. The peroxidase signal was visualized with nickel-intensified diaminobenzidine chromogen and then, post-intensified with silver-gold (Liposits et al., 1984).

To detect NKB synthesizing neurons, a second series of sections was incubated with a previously characterized rabbit polyclonal antiserum (IS-682, 1:100,000) against the C-terminal 28 amino acids of human preproNKB (Hrabovszky et al., 2010), followed by working dilutions of biotinylated secondary antibodies (biotinSP-antirabbit IgG; Jackson ImmunoResearch Laboratories; 1:500; $1 \mathrm{~h})$ and the $A B C$ reagent $(1: 1000 ; 1 \mathrm{~h})$. The signal was visualized with silver-gold-intensified Ni-DAB, as in case of kisspeptin-IR neurons.

\section{DETECTION OF GnRH NEURONS}

Following the detection of kisspeptin or NKB immunoreactivity, GnRH neurons were detected with a new guinea pig antiserum to GnRH (\#1018; 1:50,000). The primary antibodies were reacted with biotin-SP-anti-guinea pig IgG (Jackson ImmunoResearch; $1: 500 ; 1 \mathrm{~h})$ and $\mathrm{ABC}(1: 1000 ; 1 \mathrm{~h})$ and then, immunoreactivity was visualized with $\mathrm{DAB}$ chromogen alone.

To generate the \#1018 antiserum, an immunization antigen was prepared by conjugating $4 \mathrm{mg}$ mammalian $\mathrm{GnRH}$ to $25 \mathrm{mg}$ bovine thyroglobulin with $12 \mathrm{mg}$ 1-ethyl-3-(3-dimethylaminopropyl) carbodiimide in $4 \mathrm{ml} 100 \mathrm{mM}$ MES buffer ( $\mathrm{pH} 4.7$ ). Unconjugated peptides were removed from the antigen solution by dialysis against $0.1 \mathrm{M}$ phosphate buffered saline (PBS, $\mathrm{pH} 7.6 ; 3 \times 8 \mathrm{~h}$ ). Two adult female guinea pigs were immunized intradermally (i.d.) with $10 \mu \mathrm{g}$ antigen in $500 \mu \mathrm{l}$ solution. For initial immunization, $10 \mu \mathrm{g}$ antigen complex in $250 \mu \mathrm{l}$ PBS was emulsified with an equal volume of Freund's complete adjuvant (Sigma). Subsequent boosts with Freund's incomplete adjuvant were administered at 2-week intervals. Antisera were sampled from the ear 1 week after each booster injection and tested at various dilutions on tissue sections of the mouse preoptic area (for GnRH cell bodies) and median eminence (for GnRH axons). Upon achievement of the appropriate serum titer ( 3 months after the beginning of immunization), the animals were exsanguinated. The blood was allowed to clot and serum was collected. Sodium azide was added at $0.1 \%$ and antiserum aliquots were transferred to $-20^{\circ} \mathrm{C}$ for long-term storage. Antibody samples were tested with immunohistochemistry on paraformaldehyde-fixed mouse and human tissue sections. For peroxidase-based detection of $\mathrm{GnRH}$, various dilutions of the primary antibodies were made with $2 \%$ normal horse serum in PBS and applied to the sections for $16-48 \mathrm{~h}$. The primary antibodies were reacted with biotinylated secondary antibodies (biotin-SP-anti-guinea pig IgG; Jackson ImmunoResearch Laboratories; 1:500) and the ABC Elite reagent for $60 \mathrm{~min}$ each. The peroxidase signal was visualized with $\mathrm{Ni}-\mathrm{DAB}$ chromogen. As one positive control for the specificity of GnRH cell body labeling, the immunofluorescent detection of GnRH was performed on preoptic sections of GnRH-GFP transgenic mice in which GnRH neurons exhibit green fluorescence (Suter et al., 2000). As a second positive control also applicable to human test sections, dual-immunofluorescent visualization of GnRH immunoreactivity was carried out with one of the new guinea pig antisera (\#1018 or \#1035), in combination with a reference rabbit GnRH antiserum (LR1; 1: 5000) that was kindly provided by Dr. R. A. Benoit and used in previous publications from different laboratories, including our own (Hrabovszky et al., 2007, 2010). In both control experiments, incubation with guinea pig GnRH antisera was followed by donkey antiguinea pig-Cy3 (1: 1000; Jackson ImmunoResearch) for $5 \mathrm{~h}$. The LR1 antibody was reacted with donkey anti-rabbit-FITC (1:200) for $5 \mathrm{~h}$.

\section{TRIPLE-IMMUNOFLUORESCENT VISUALIZATION OF PREPRONKB, KISSPEPTINS, AND GnRH}

A series of sections was used to study the colocalization pattern of $\mathrm{NKB}$ and kisspeptin in neuronal afferents to $\mathrm{GnRH}$ neurons. Incubation in a cocktail of primary antibodies (rabbit anti-preproNKB, 1:1000; sheep anti-kisspeptin, 1:1000; guinea pig anti-GnRH, 1:3000) for $48 \mathrm{~h}$ at $4^{\circ} \mathrm{C}$ was followed by a cocktail of fluorochrome-conjugated secondary antibodies (all 
raised in donkey; anti-rabbit-FITC, 1:250; anti-sheep-Cy3, 1:1000; anti-guinea pig-AMCA, 1:100; Jackson ImmunoResearch) for $5 \mathrm{~h}$.

\section{SECTION MOUNTING AND COVERSLIPPING}

Sections dual-immunostained with the combination of silvergold-intensified Ni-DAB and DAB chromogens were mounted on microscope slides from Elvanol, air-dried, dehydrated with 95\% ( $5 \mathrm{~min}$ ), followed by $100 \%(2 \times 5 \mathrm{~min})$ ethanol, cleared with xylene $(2 \times 5 \mathrm{~min})$, and coverslipped with DPX mounting medium (Fluka Chemie; Buchs, Switzerland). Representative microscopic images were prepared with an AxioCam MRc 5 digital camera mounted on a Zeiss AxioImager M1 microscope using the AxioVision 4.6 software (Carl Zeiss, Göttingen, Germany). Sections processed for immunofluorescent experiments were mounted from 0.1 M Tris-HCl buffer ( $\mathrm{pH}$ 7.6) and coverslipped with the aqueous mounting medium Mowiol.

\section{ANALYSES AND STATISTICS}

To exclude any bias, the immunostained samples were randomized, coded, and analyzed by investigators blind to the origin of samples. All statistical comparisons were carried out with one-way ANOVA followed by Newman-Keuls post hoc test using the Statistica 8.0 software package (StatSoft, Inc., Tulsa, USA). Immunohistochemical samples from five to nine male and five to seven female subjects were included in each experiment and statistical group.

\section{Experiment 1. Studies of the perikaryon size of kisspeptin-IR and preproNKB-IR neurons}

To determine the average size of kisspeptin-IR and peproNKB-IR cell bodies, 10-30 solitary neurons, which showed no overlap with one another, were identified in digital images of the Inf from each individual. To exclude immunoreactive neuronal processes from the area analyzed, the tissue area surrounding each immunolabeled neuron was erased using the Adobe Photoshop CS software. The digital images of selected cell bodies were compiled into TIF files and opened for area/cell body analysis with the Image J software (public domain at http://rsb.info.nih.gov/ij/download/src/). A threshold was determined and set to only highlight the labeled cell bodies in all specimens. The signal areas were measured this way and then, converted to square micrometer using appropriate calibration. For each human subject the mean profile area of labeled perikarya was derived from an average of 10-30 labeled cells.

\section{Experiment 2. Studies of the incidence of kisspeptin-IR and preproNKB-IR cell bodies in the Inf}

As validated previously (Hrabovszky et al., 2010), kisspeptin-IR and preproNKB-IR cell bodies were counted in the Inf at $100 \times$ magnification in a $0.25-\mathrm{mm}^{2}$ counting area, with the aid of a $5 \times 5$ ocular grid. Each human individual was finally characterized with the highest number of immunoreactive cell bodies per $0.25 \mathrm{~mm}^{2}$ counting area, as determined from two to six sections.

\section{Experiment 3. Studies of the regional density of kisspeptin-IR and preproNKB-IR fibers}

Digital images were captured in regions of the Inf that contained the bulk of kisspeptin-IR and preproNKB-IR cell bodies. The files were opened with the Adobe Photoshop CS software. The immunolabeled cell bodies were erased ("eraser tool") from the photomicrographs. The remaining images were compiled into TIF files and opened with the Image J software. The regional fiber density in each photograph was defined as the area occupied by immunoreactive fibers/total area. For each subject, the mean fiber density was derived from one to three digital images.

\section{Experiment 4. Studies of the frequency of kisspeptin-IR and preproNKB-IR appositions onto GnRH-IR neurons}

One or two sections were selected from each individual to analyze the number of axonal contacts along the outlines of GnRH neurons and their dendrites. The counting was carried out using a $100 \times$ oil immersion objective. A contact was defined using stringent criteria that were applied consistently, as follows. The axon and the $\mathrm{GnRH}$ profile had to be in the same focus plane without any visible intervening gap, and dubious instances of partial overlap were not considered. For each subject, both the mean number of contacts/GnRH soma and the mean number of contacts $/ 100 \mu \mathrm{m}$ GnRH dendrite were measured.

\section{Experiment 5. Colocalization studies of kisspeptins and preproNKB in neuronal afferents to GnRH neurons}

One section from the triple-immunofluorescent specimens of the Inf was selected from each individual to analyze single- and double-labeled kisspeptin-IR and preproNKB-IR neuronal appositions onto $\mathrm{GnRH}$ neurons. Multiple stacks of optical slices $(512 \times 512$ pixels, $z$-steps $0.6 \mu \mathrm{m})$ were obtained by scanning GnRH neurons in the Inf and their kisspeptin-IR and preproNKBIR contacts using a $60 \times$ oil immersion objective and a Radiance 2100 confocal microscope (Bio-Rad Laboratories, Hemel Hempstead, UK). The three fluorochromes were detected with the following laser lines and filters: $488 \mathrm{~nm}$ for FITC, $543 \mathrm{~nm}$ for CY3 and Alexa594, $405 \mathrm{~nm}$ for AMCA, with dichroic/emission filters $560 \mathrm{~nm} / 500-540 \mathrm{~nm}$ for FITC, $650 \mathrm{~nm} / 560-610 \mathrm{~nm}$ for CY3 and Alexa594, $500 \mathrm{~nm} / 420-480 \mathrm{~nm}$ for AMCA. The separately recorded green, red, and blue channels were merged and displayed with the Laser Vox software (Bio-Rad) running on an IBM-compatible personal computer. Appositions were validated if no gap was visible between the juxtaposed profiles in at least one optical slice. A total of 394 kisspeptin-IR contacts and 337 preproNKB-IR contacts (mixed axo-dendritic and axo-somatic) were analyzed to count the percent ratios of double-labeled neuronal appositions onto the cell bodies and the dendrites of $\mathrm{GnRH}$ IR neurons. The colocalization percentages were determined in five male and six female individuals and compared.

\section{RESULTS}

\section{EXPERIMENT 1. PERIKARYON SIZE OF KISSPEPTIN-IR AND PREPRONKB-IR NEURONS}

Kisspeptin-IR cell bodies $(P=0.01)$ as well as preproNKB-IR cell bodies $(P=0.002)$ were hypertrophied and their profile area was significantly larger in the Inf of aged women $\left(284.2 \pm 27.3 \mu \mathrm{m}^{2}\right.$ for kisspeptin-IR and $298.1 \pm 19.7 \mu \mathrm{m}^{2}$ for preproNKB-IR neurons) in comparison with men $\left(154.8 \pm 19.2 \mu \mathrm{m}^{2}\right.$ for kisspeptin-IR and $190.4 \pm 20.4 \mu \mathrm{m}^{2}$ for preproNKB-IR neurons; Figures 1C,D,G,H and 2 ). 


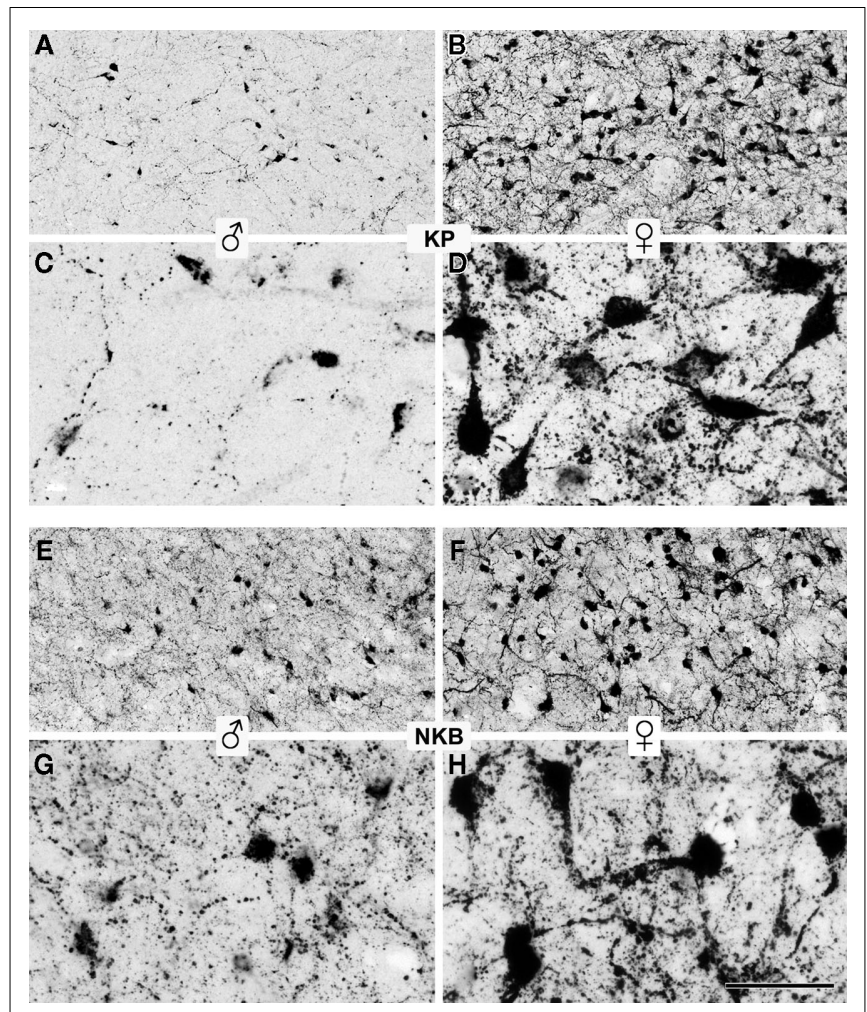

FIGURE 1 | Sexual dimorphism of kisspeptin-IR and preproNKB-IR neuronal elements in the Inf of aged human subjects. Kisspeptin (A-D) and preproNKB (E-H) immunoreactivities were visualized using the silver-gold-intensified Ni-DAB chromogen. The photomicrographs were taken from the Inf of 59-year-old male $(\mathbf{A}, \mathbf{C})$ and 62-year-old male $(\mathbf{E}, \mathbf{G})$ and 66-year-old (B,D,F,H) female individuals. Both kisspeptin-IR (D) and preproNKB-IR $(\mathbf{H})$ cell bodies are larger in postmenopausal women compared with aged men ( $\mathbf{C}$ and $\mathbf{G}$, respectively). Neuronal hypertrophy reflects lack of estrogen negative feedback in postmenopausal women. Kisspeptin neurons also show other robust sex differences in that the number of KP-IR cell bodies and the density of kisspeptin-IR fibers are much higher in aged women (B) compared with men (A). The number of preproNKB-IR cell bodies is also higher in women (F) compared with men (E), but the difference is less dramatic than in case of kisspeptin-IR cell bodies. No obvious sexual dimorphism exists in the regional density of NKB fibers (E-H). For quantitative comparisons, see Figures 2-4. Scale bar $=200 \mu \mathrm{m}$ in $(\mathbf{A}, \mathbf{B}, \mathbf{E}, \mathbf{F})$ and $50 \mu \mathrm{m}$ in $(\mathbf{C}, \mathbf{D}, \mathbf{G}, \mathbf{H})$.

\section{EXPERIMENT 2. INCIDENCE OF KISSPEPTIN-IR AND PREPRONKB-IR CELL BODIES IN THE Inf}

Quantitative analysis of the labeled cell bodies (using the maximal number of labeled cell bodies per $0.25 \mathrm{~mm}^{2}$ counting frame for each male and female individual) revealed the following differences

In males, preproNKB-IR cell bodies showed a significantly higher incidence compared with kisspeptin-IR cell bodies $(P=0.0005)$. PreproNKB-IR neurons outnumbered kisspeptinIR neurons by $120 \%$ (Figures $\mathbf{1 A , E}$ and $\mathbf{3}$ ).

In females, the mean incidence of preproNKB-IR cell bodies was only $23 \%$ higher than that of kisspeptin-IR perikarya. This subtle difference was not statistically significant $(P=0.28$; Figures 1B,F and 3).

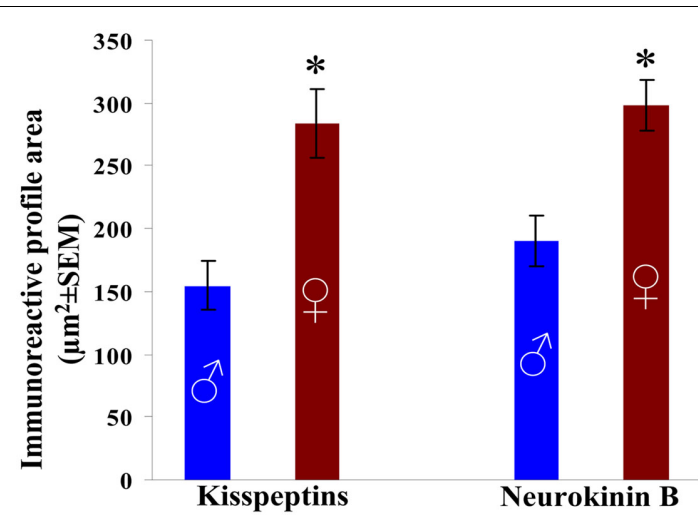

FIGURE 2 | Size of kisspeptin-IR and preproNKB-IR perikarya in the Inf of aged men and women. The mean surface area covered by the silvergold-intensified Ni-DAB chromogen was used as an index of perikaryon size. The area of immunolabeled cell bodies differs between aged men and women in case of both peptides. The difference likely reflects a robust neuronal hypertrophy in postmenopausal females. ${ }^{*} P<0.05$.

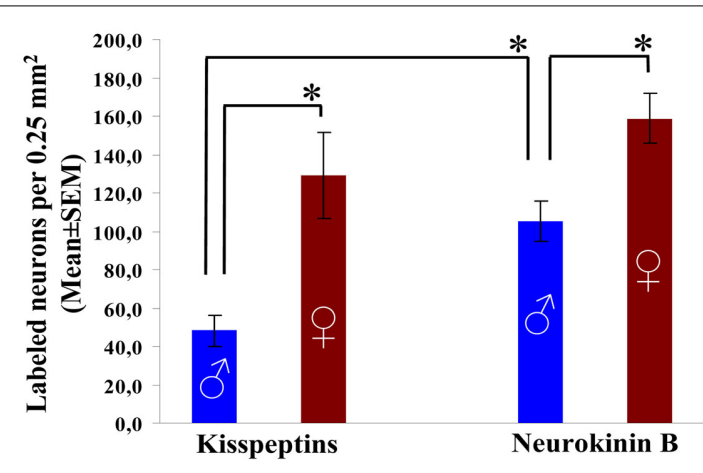

FIGURE 3 | Regional abundances of kisspeptin-IR and preproNKB-IR neuronal perikarya in the Inf of aged men and women. The maximal number of immunoreactive cell bodies per $0.25 \mathrm{~mm}^{2}$ counting frame (1-6 per subject) was determined with the aid of an ocular frame and used as the index of regional neuron density. The abundance of kisspeptin neurons determined this way is much higher in aged women compared with aged men, whereas the number of NKB cell bodies is only slightly (but significantly) higher in females. Note also that men, unlike women, contain 2.2-times as many preproNKB-IR as kisspeptin-IR cell bodies. ${ }^{*} P<0.05$.

Kisspeptin-IR cell bodies showed a 170\% higher mean density (incidence of cell bodies per $0.25 \mathrm{~mm}^{2}$ counting frame) in females compared with males. This robust sex difference was statistically significant $(P=0.002$; Figures $\mathbf{1 A}, \mathbf{B}$ and 3$)$.

PreproNKB-IR cell bodies showed a 51\% higher mean incidence in females vs. males. This numerical sex difference was much less conspicuous than for kisspeptin-IR cell bodies, but statistically significant $(P=0.006$; Figures $\mathbf{1 E , F}$ and 3$)$.

\section{EXPERIMENT 3. REGIONAL DENSITY OF KISSPEPTIN-IR AND PREPRONKB-IR FIBERS}

The Inf of aged men exhibited a few kisspeptin-IR fibers only, in contrast with dense fiber networks in the Inf of postmenopausal women (Figures 1A-D). PreproNKB-IR axons did not seem to 
show this robust sex difference (Figures 1E-H). Quantitative analysis of labeled axons (area covered by immunohistochemical signal per total area) established the following differences:

In the Inf of males, the mean density of preproNKB-IR axons was $180 \%$ higher than that of kisspeptin-IR fibers. The difference was statistically significant ( $P=0.004$; Figures $\mathbf{1 A}, \mathrm{C}, \mathbf{E}, \mathrm{G}$ and 4 ).

In the Inf of females, the densities of preproNKB-IR and kisspeptin-IR fibers did not differ statistically $(P=0.41$; Figures 1B,D,F,H and 4).

Kisspeptin-IR fibers showed a robust sexual dimorphism, with a $161 \%$ higher density in females vs. males. This difference was statistically significant ( $P=0.02$; Figures $1 \mathrm{~A}-\mathrm{D}$ and 4$)$.

PreproNKB-IR fibers showed only $8.4 \%$ higher mean density in females than in males and the sexes did not differ statistically $(P=0.60$; Figures 1E-H and 4), in contrast with the dramatic and significant sexual dimorphism of the kisspeptin-IR fiber network.

\section{EXPERIMENT 4. FREOUENCY OF KISSPEPTIN-IR AND PREPRONKB-IR APPOSITIONS ONTO GnRH-IR NEURONS}

Both guinea pigs (\#1018 and \#1035) that were immunized against the mammalian GnRH raised antibodies that reacted specifically with GnRH neurons in mouse and human tissue sections (Figure 5). Using peroxidase-based immunohistochemistry, IR neurons exhibited the typical fusiform shape and distribution pattern of $\mathrm{GnRH}$ neurons in the medial preoptic area of mice (Figure 5A). In immunofluorescent experiments on tissue sections from GnRH-GFP transgenic mice, the immunoreactive cell bodies also exhibited the green fluorescence of GFP (Figures 5B-E). The combined use of the new guinea pig antisera and the LR1 reference rabbit antiserum on human test sections provided an additional evidence for labeling specificity (Figures 5F-I). The

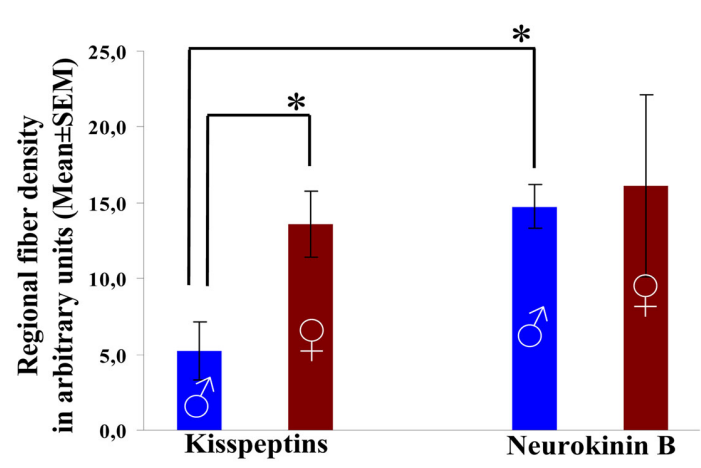

FIGURE 4 | Density of kisspeptin-IR and preproNKB-IR fibers in the Inf of aged men and women. The area covered by immunoreactive fibers (divided by the total area analyzed) was determined with the Image J software in digital photographs of the Inf and used as an index of regional fiber density (presented in arbitrary units). Areas of the photomicrographs that were occupied by labeled cell bodies and their proximal dendrites were erased using the Adobe Photoshop software and excluded from the analysis. The density of preproNKB-IR fibers defined this way was 2.8-fold as high as the density of kisspeptin-IR fibers in aged males, but not different in aged females. The density of kisspeptin-IR fibers showed a dramatic sexual dimorphism and was 2.5-fold higher in aged females vs. males. The mean density of preproNKB-IR fibers did not differ significantly between sexes. ${ }^{*} P<0.05$. optimal dilutions of the new antisera were 1:50,000-1:200,000 for peroxidase-based immunohistochemistry and 1:3,000-1:10,000 for immunofluorescence using fluorochrome-conjugated secondary antibodies.

Sections double-labeled for kisspeptins and $\mathrm{GnRH}$ or preproNKB and GnRH used silver-gold-intensified Ni-DAB and DAB chromogens, in combination. The high-power light microscopic analysis of these sections confirmed our previous observation (Hrabovszky et al., 2010) that kisspeptin-IR axons establish axosomatic and axo-dendritic contacts on GnRH neurons of the Inf (Figures 6A-D), in addition to axo-axonal contacts in the infundibular stalk that were not analyzed here. In the present study, we observed similar axo-somatic, axo-dendritic, and axoaxonal (not shown) appositions between preproNKB-IR axons and GnRH-IR neurons (Figures 6E-H).

The semiquantitative analysis of kisspeptin-IR contacts on GnRH-IR cell bodies and dendrites revealed a significantly heavier kisspeptin-IR input to the cell bodies $(P=0.03)$ and the dendrites $(P=0.021)$ of GnRH-IR neurons in women compared with men (Figure 7).

In both sexes, GnRH-IR cell bodies and dendrites received significantly heavier preproNKB-IR input than kisspeptin-IR input (male cell bodies: $P=0.002$; male dendrites: $P=0.0002$; female cell bodies: $P=0.02$; female dendrites: $P=0.02$; Figure 7 ).

In contrast with the dramatic sexual dimorphism of kisspeptinIR inputs, no significant sex difference was observed in the incidence of preproNKB-IR axo-somatic and axo-dendritic juxtapositions to GnRH-IR neurons (axo-dendritic contacts: $P=0.24$; axo-somatic contacts: $P=0.36$; Figure 7 ). However, there was a trend for somewhat more preproNKB-IR contacts in females.

\section{EXPERIMENT 5. COLOCALIZATION OF KISSPEPTINS AND PREPRONKB IN NEURONAL AFFERENTS TO GnRH NEURONS}

The triple-immunofluorescent specimens contained numerous kisspeptin-IR and preproNKB-IR fibers. The sensitivity of the approach was not sufficient to visualize high numbers of kisspeptin-IR and preproNKB-IR cell bodies. The axonal kisspeptin and preproNKB immunolabeling showed a partial overlap only and GnRH neurons were most frequently contacted by single-labeled axons both in males and females (Figure 8). The semiquantitative analysis of afferent contacts onto GnRH-IR cell bodies and dendrites (Figure 9) established that $8.8 \pm 5.5 \%$ of preproNKB-IR afferents in males also contained kisspeptin immunoreactivity. The ratio of double-labeled afferents was $31.3 \pm 4.9 \%$ in females $(P=0.01)$. Similarly, the percentage of kisspeptin-IR contacts that colocalized preproNKB signal was significantly higher $(P=0.033)$ in females $(25.8 \pm 2.4 \%)$ vs. males $(10.2 \pm 4.6 \%)$.

\section{DISCUSSION \\ SEX DIFFERENCE IN PERIKARYON SIZE OF KISSPEPTIN AND PREPRONKB NEURONS}

The studies of a putative sex difference in the perikaryon size of kisspeptin-IR and preproNKB-IR neurons (mean cross-sectional area of immunoreactive neurons) relied on previous work indicating that the profile area of neurons in the Inf is significantly greater in postmenopausal women than in aged men (Rance 


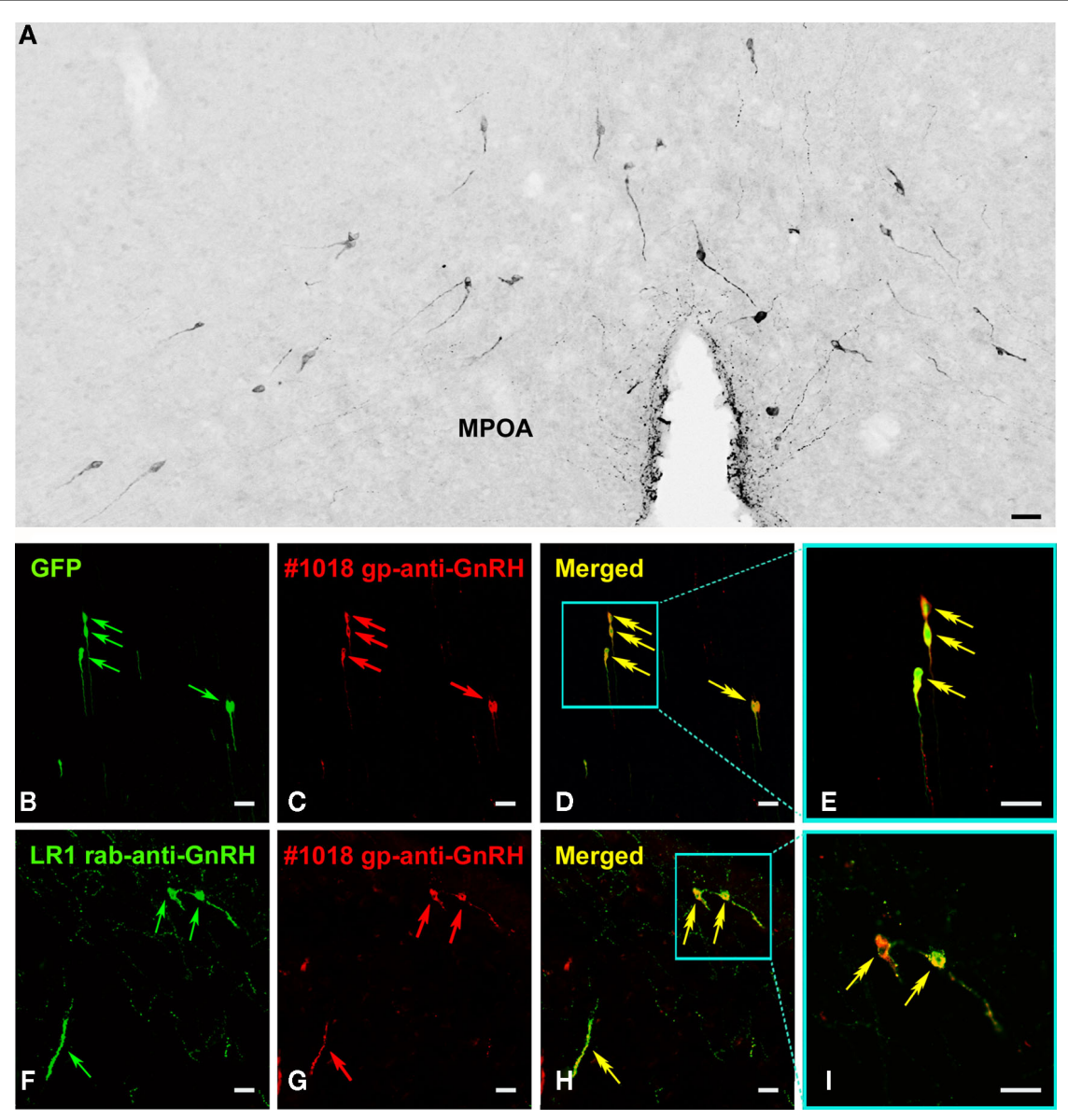

FIGURE 5 | Specificity test results using a new guinea pig GnRH antiserum. Using a new polyclonal GnRH antiserum (\#1018) for peroxidase-based immunohistochemistry, the Ni-DAB chromogen reveals GnRH-IR neurons and their fibers in the medial preoptic area (MPOA) of mice. The labeled neurons exhibit characteristic fusiform shapes (A). In positive control experiments, the distribution of the immunofluorescent $\mathrm{GnRH}$ signal in labeled cell bodies [red arrows in (C)] shows a good agreement with the native green fluorescence of GnRH-GFP neurons [green arrows in (B)] of et al., 1993). This morphometric sex difference is thought to result primarily from postmenopausal alterations of the female Inf. In 1966, Sheehan and Kovacs reported neuronal hypertrophy in a subregion of the Inf termed subventricular nucleus. The hypertrophied neurons contained enlarged nuclei and nucleoli and a prominent Nissl substance. They occurred in female individuals above 50 years of age and similarly, in women with post-partum hypopituitarism (Sheehan and Kovacs, 1966). Sheehan (1967) concluded that neuronal hypertrophy is a consequence of ovarian failure. A series of in situ hybridization studies from Rance and co-workers established later that the hypertrophied neurons express estrogen receptor- $\alpha$ (Rance et al., 1990), substance P (Rance and Young, 1991), NKB (Rance and Young, 1991), kisspeptin (Rometo et al., 2007), and prodynorphin (Rometo and Rance, 2008) mRNAs. It was concluded that the neuronal hypertrophy is not a compensatory response to neuronal cell death, because the number of neurons in the Inf was similar in pre- and transgenic mice. Double arrows in (D) [merged from (B,C)] and (E) [high-power image of framed region in (D)] point to double-labeled neurons. The dual-immunofluorescent visualization of $\mathrm{GnRH}-\mathrm{IR}$ neurons in the human hypothalamic infundibular nucleus provides additional evidence that a reference rabbit antiserum [LR1; (F)] and the new guinea pig antiserum (G) recognize the same neurons. Double arrows in $\mathbf{( H )}[$ merged from $\mathbf{( F , G ) ] ~ a n d ~ ( I ) ~}$ [high-power image of framed region in $\mathbf{( H )}$ ] point to the dual-labeled $\mathrm{GnRH}$ cell bodies and their processes. Scale bars $=50 \mu \mathrm{m}$. postmenopausal women (Abel and Rance, 2000). Ovariectomy was also capable of inducing the hypertrophy of kisspeptin mRNA expressing neurons in the Inf of monkeys (Rometo et al., 2007), providing experimental evidence to the concept that the enlargement of neuronal perikarya is a consequence of the loss of estrogen.

The morphometric analyses of kisspeptin-IR and preproNKBIR neurons in our present study revealed a robust sex difference in the size (mean profile area) of kisspeptin-IR as well as preproNKB-IR neurons in the Inf of aged men and women. The mean cross-sectional area we determined for postmenopausally hypertrophied neurons $\left(284.2 \pm 27.3 \mu \mathrm{m}^{2}\right.$ for kisspeptin-IR and $298.1 \pm 19.7 \mu \mathrm{m}^{2}$ for preproNKB-IR neurons) agrees well with the profile area of kisspeptin mRNA expressing hypertrophied neurons $\left(280.9 \pm 17.3 \mu \mathrm{m}^{2}\right)$, as measured previously in toluidine blue-stained samples (Rometo et al., 2007). Moreover, profile area values we determined for aged 

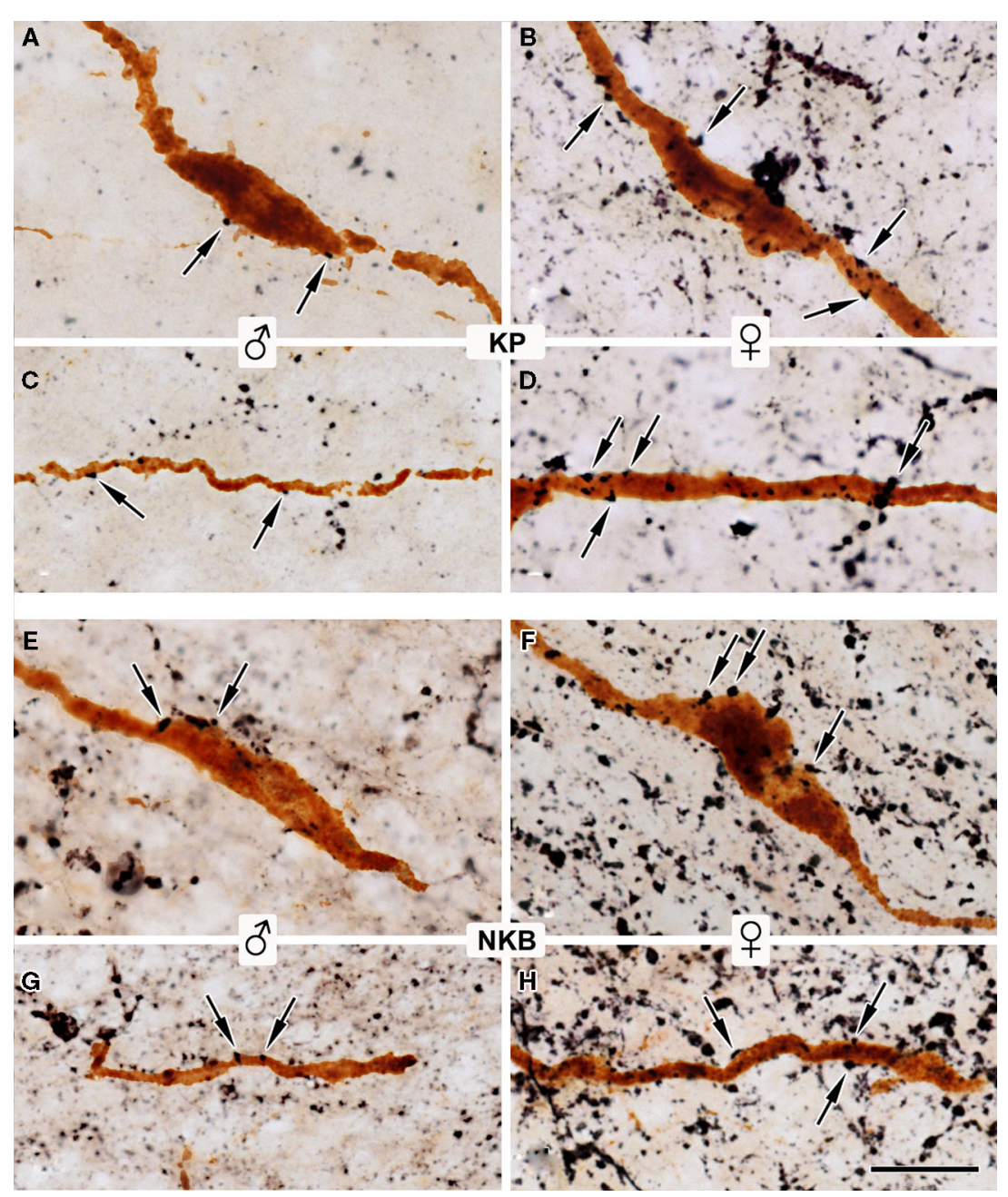

FIGURE 6 | Identification of kisspeptin-IR and preproNKB-IR afferent contacts on GnRH-IR neurons of the Inf. Sections double-labeled for kisspeptins (KP) and GnRH (A-D) or preproNKB (NKB) and GnRH (E-H) with the combined use of silver- gold-intensified Ni-DAB and DAB chromogens demonstrate that kisspeptin-IR axons establish axo-somatic $(\mathbf{A}, \mathbf{B})$ and axo-dendritic $(\mathbf{C}, \mathbf{D})$ contacts (arrows) on $\mathrm{GnRH}$ neurons of the Inf. Similar contacts can also be observed in high numbers between preproNKB-IR axons and $\mathrm{GnRH}$ neurons [arrows in $(\mathbf{E}-\mathbf{H})$ ]. The kisspeptin-IR input is significantly heavier on $\mathrm{GnRH}-\mathrm{IR}$ neurons from women vs. men [compare (B) to (A) and (D) to (C)]. In both sexes, $\mathrm{GnRH}-\mathrm{IR}$ cell bodies and dendrites receive more preproNKB-IR (E-H) than kisspeptin-IR (A-D) input. In contrast with the dramatic sexual dimorphism of kisspeptin-IR inputs, no significant sex difference can be observed in the incidence of preproNKB-IR axo-somatic (E,F) and axo-dendritic $(\mathbf{G}, \mathbf{H})$ juxtapositions to $\mathrm{GnRH}-\mathrm{IR}$ neurons. [(A,C): 59-year-old male; (E,G): 52-year-old male; (B,D): 57-year-old female; $\mathbf{( F , H ) : ~}$ 64-year-old female]. For quantitative comparisons, see Figure 7. Scale bar $=20 \mu \mathrm{m}$. men $\left(154.8 \pm 19.2 \mu \mathrm{m}^{2}\right.$ for kisspeptin-IR and $190.4 \pm 20.4 \mu \mathrm{m}^{2}$ for preproNKB-IR neurons) are also comparable to the mean cross-sectional area of toluidine blue-stained hypertrophied neurons in the Inf of older men $\left(176.6 \pm 1.7 \mu \mathrm{m}^{2}\right.$; Rance et al., 1993), in spite of differences in the applied histochemical approaches.

It is interesting to note that an aging-related neuronal hypertrophy has also been noticed in the male Inf, although it did not reach the magnitude of postmenopausal hypertrophy (Rance et al., 1993). The phenotype of hypertrophied neurons in the male Inf requires clarification. Given that sex steroid levels only decline modestly and exhibit considerable individual variations among aging males (Araujo and Wittert, 2011), the mild increase in the size of neurons in the Inf of aging men may not be directly linked to a decrease of sex steroid levels, but instead, may partly reflect an age-related decrease in the sensitivity of the male reproductive axis to androgen. This would be in accordance with the reported age-related decline of androgen negative feedback (Veldhuis et al., 2010).

The explanation for the sex difference we report here for the immunoreactive profile areas of kisspeptin-IR and preproNKBIR neurons represents a sex difference in aging-related neuronal hypertrophy. In women, this reaches a higher magnitude due to ovarian failure after menopause, whereas in men the presence of testosterone continues to inhibit the synthetic activity of kisspeptin and preproNKB neurons in the Inf. 


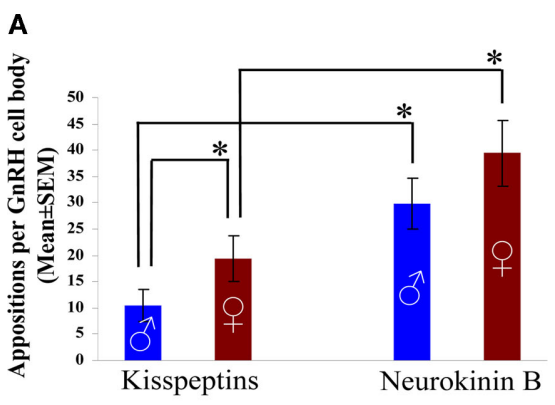

FIGURE 7 | Incidence of kisspeptin-IR and preproNKB-IR contacts on GnRH-IR neurons of the infundibular nucleus. High-power light microscopic analysis of sections, dual-immunolabeled with the combined use of silver- gold-intensified Ni-DAB and DAB chromogens (see Figure 6), was carried out to determine the relative frequencies of kisspeptin-IR (left column pairs) and preproNKB-IR (right column pairs) neuronal appositions onto the somata $(\mathbf{A})$ and dendrites $(\mathbf{B})$ of $\mathrm{GnRH}-\mathrm{IR}$ neurons. The counts were obtained from all $\mathrm{GnRH}-\mathrm{IR}$ cell bodies and dendrites that were identified in 1-3 sections of the Inf from each of eight male and six female individuals. The innervation patterns are highly similar on $\mathrm{GnRH}$ cell bodies

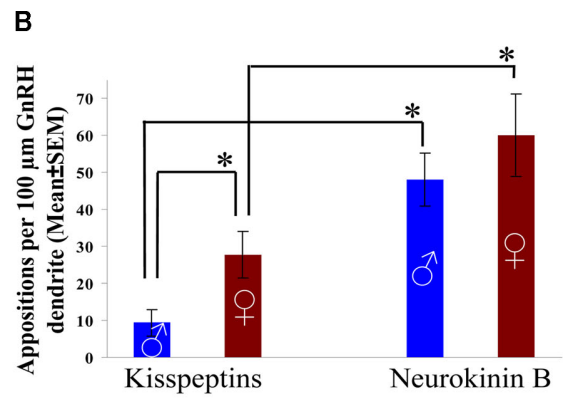

(A) and dendrites (B). Note that the number of preproNKB-IR contacts is significantly higher than the number of kisspeptin-IR contacts on both the somatic (A) and the dendritic (B) membranes and in both males and females. The kisspeptin-IR input to $\mathrm{GnRH}$ cell bodies (A) and dendrites (B) is highly sexually dimorphic. The mean incidence of kisspeptin-IR contacts is $88.2 \%$ higher on $\mathrm{GnRH}-\mathrm{IR}$ cell bodies and $177.4 \%$ higher on $\mathrm{GnRH}-\mathrm{IR}$ dendrites in postmenopausal females vs. aged males. In contrast, there is no statistical difference between the two sexes in the incidences of preproNKB-IR contacts, although the means are somewhat higher in females. ${ }^{*} P<0.05$.

\section{HIGHER RELATIVE LEVELS OF PREPRONKB VS. KISSPEPTIN IMMUNOLABELING}

An important observation in this study was the heavier preproNKB than kisspeptin immunolabeling in the Inf, in particular, in aged men. This difference represents a biological rather than technical phenomenon, given that both kisspeptin and NKB immunoreactivities showed obvious sex-dependent patterns instead of random variations across tissue specimens. The observation that the Inf contained 2.2-times as many preproNKB-IR as kisspeptin-IR cell bodies, 2.8-times as high preproNKB-IR as KP-IR fiber densities and 3-5-times as many preproNKB-IR as KP-IR neuronal contacts on $\mathrm{GnRH}$ neurons, indicate that a large subset of $\mathrm{NKB}$ neurons do not synthesize detectable amounts of kisspeptins in the Inf of aged men. This conclusion gains additional support from immunofluorescent results which confirmed a substantial level of mismatch between kisspeptin-IR and preproNKB-IR axons in the Inf, including higher numbers of single-labeled than doublelabeled preproNKB-IR as well as kisspeptin-IR afferent contacts onto GnRH neurons. The sensitivity of the immunofluorescent detection method did not allow us to determine the exact percentages of overlap between kisspeptin and preproNKB-synthesizing neuronal cell bodies in the two sexes.

The dominance of preproNKB over kisspeptin labeling was also present in postmenopausal females, although the differences did not reach the same magnitudes as in men. Notably, samples from postmenopausal women showed only 1.2-times as many preproNKB-IR as kisspeptin-IR neurons, only 1.6-2.2-times as many preproNKB-IR as kisspeptin-IR afferent contacts on GnRH neurons, and no significant difference in the overall density of preproNKB-IR vs. kisspeptin-IR fibers in the Inf.

The partial segregation of the kisspeptin from the NKB immunolabeling in our study, with the dominance of the latter, reveals a difference from the female sheep (Goodman et al., 2007) and rodents (Navarro et al., 2009) where the majority of kisspeptin neurons in the ARC also contain NKB (and dynorphins). Of note, a more recent study of male mice identified about twice as many NKB mRNA expressing as kisspeptin mRNA expressing neurons in the ARC (Navarro et al., 2011). Together with the previous report on females (Navarro et al., 2009), this observation indicates a sex difference in the extent of coexpression. This possible sexual dimorphism is reminiscent to our observation that NKB cell numbers exceed kisspeptin cell numbers by more in aged human males than in females. A different colocalization pattern has been observed recently in the ARC of adults in castrated male monkey model in which no NKB neurons without kisspeptin labeling were observed and only 40-60\% of kisspeptin-IR neurons contained preproNKB immunoreactivity (Ramaswamy et al., 2010).

Two possibilities may explain the sex difference in relative levels of preproNKB vs. kisspeptin immunolabeling in our study. First, the putative organizational effects of a developmental sex steroid exposure may generate a lower degree of colocalization in males than in females which may be maintained throughout life. Second, the different levels of negative sex steroid feedback between aged men and women may differentially influence the expression patterns of the two peptides. The dramatically low kisspeptin levels in aged men may reflect the higher reactivity of the KISS1 gene to the suppressive effects of testosterone. Kisspeptin (Rometo et al., 2007; Kim et al., 2009; Eghlidi et al., 2010) as well as NKB (Rance and Bruce, 1994; Eghlidi et al., 2010) mRNAs have lower premenopausal than postmenopausal levels in primates, indicating that sex steroids negatively regulate the expression of both neuropeptides. These data are also in accordance with the negative regulation of kisspeptin and NKB expression by sex steroids in various animal species (Rance and Young, 1991; Abel et al., 1999; Danzer et al., 1999; Dellovade and Merchenthaler, 2004; Smith et al., 2005a,b, 2006a; Adachi et al., 2007; Kauffman et al., 2007; Kim et al., 2009; Navarro et al., 2009; Eghlidi et al., 2010). In our immunohistochemical studies of aged women, we observed high levels of kisspeptin immunoreactivities that approached the levels of preproNKB-IR labeling. From this we 

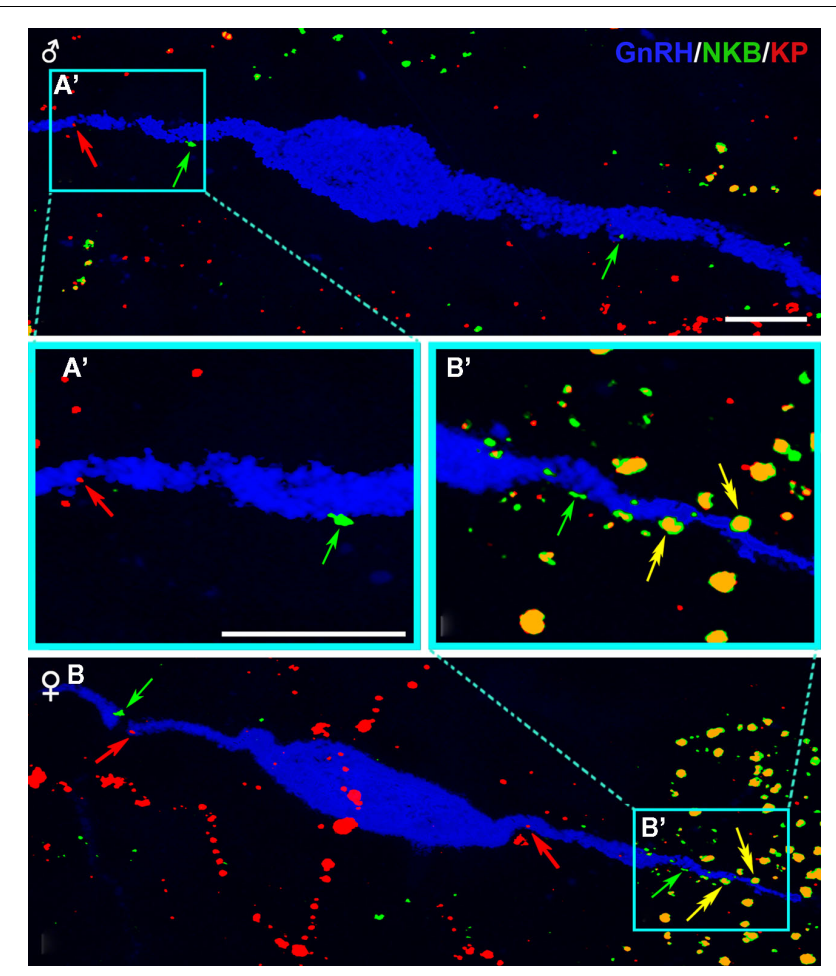

FIGURE 8 | Detection of preproNKB and kisspeptin immunoreactivities in neuronal appositions onto GnRH neurons of the Inf. The

simultaneous immunofluorescent detection of preproNKB (green color), kisspeptins (red color), and GnRH (blue color), followed by confocal analysis revealed direct appositions of single- and double-immunolabeled (yellow color) axons onto $\mathrm{GnRH}-\mathrm{IR}$ cell bodies and dendrites. Note in stacks of optical slices that preproNKB/kisspeptin dual-IR appositions (yellow) are more typical in postmenopausal female [(B) and high-power image of the framed dendritic region $\left.\left(\mathbf{B}^{\prime}\right)\right]$ than in aged male [(A) and high-power inset $\left.\left(\mathbf{A}^{\prime}\right)\right]$ subjects. Red and green arrows indicate afferent contacts that are single-labeled for kisspeptins and preproNKB, respectively, whereas yellow double-arrows indicate double-labeled appositions. For quantitative results of sex comparisons, see Figure $\mathbf{9}$. Scale bars $=10 \mu \mathrm{m}\left[\right.$ Bars in $\left(\mathbf{A}, \mathbf{A}^{\prime}\right)$ also refer to $\left(\mathbf{B}, \mathbf{B}^{\prime}\right)$, respectively].

propose that the postmenopausal disruption of negative estrogen feedback exerts more dramatic effects on KISS1 compared with preproNKB expression.

It is interesting to note that preproNKB-IR appositions occurred more frequently than kisspeptin-IR contacts on $\mathrm{GnRH}$ neurons. There was no sex difference in the incidence of preproNKB-IR contacts on GnRH neurons, although NKB neurons were present in higher numbers in the Inf of aged women vs. men. It is possible that preproNKB-IR systems outside the Inf, that are not sexually dimorphic, contribute significantly to these afferent contacts. The putative origins of such inputs may include $\mathrm{NKB}$ neurons in the periventricular nucleus and the bed nucleus of the stria terminalis (Hrabovszky et al., 2010). It is also possible that the number of preproNKB-synthesizing neurons is similar in the Inf of the two sexes, but different peptide synthesis and release dynamics cause a sex differences in the number of detectable cell bodies, without affecting preproNKB immunoreactivity in fibers and their terminals on GnRH neurons.

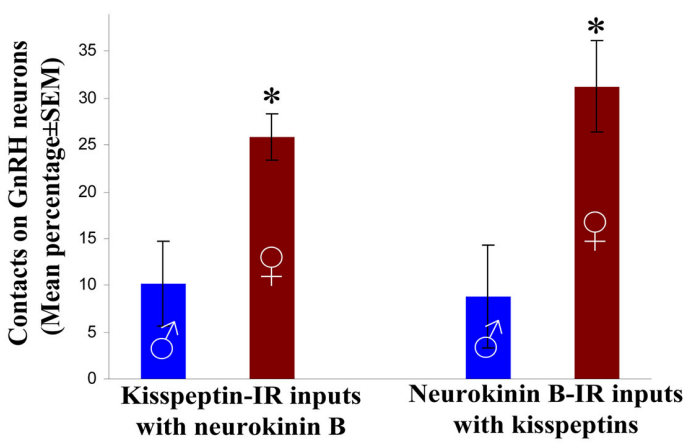

FIGURE 9 | Sex difference in the colocalization patterns of kisspeptins and preproNKB in neuronal afferents to GnRH neurons. As revealed on triple-immunofluorescent specimens, $\mathrm{GnRH}$ neurons receive kisspeptin-IR, preproNKB-IR, and double-labeled neuronal contacts. The percentage of kisspeptin-IR contacts that colocalized preproNKB signal is significantly higher in females $(25.8 \pm 2.4 \%)$ vs. males $(10.2 \pm 4.6 \%)$. Similarly, while only $8.8 \pm 5.5 \%$ of preproNKB-IR afferents in males contain kisspeptin immunoreactivity, the extent of this colocalization is $31.3 \pm 4.9 \%$ in females. ${ }^{*} P<0.05$.

\section{SEX DIFFERENCES IN KISSPEPTIN IMMUNOREACTIVITY}

Kisspeptin is a strong stimulator of luteinizing hormone release in both women and men (Dhillo et al., 2005, 2007), with a sexual dimorphism in kisspeptin responsiveness of the reproductive axis. While systemic kisspeptin-10 administration stimulates gonadotropin secretion in adult men, it only elicits luteinizing hormone and follicle stimulating hormone secretion in the preovulatory phase, but not during most of the follicular phase, of the menstrual cycle in women (Jayasena et al., 2011).

Kisspeptins represent the main output signal from Kisspeptin/ $\mathrm{NKB} /$ Dynorphin (KNDy) neurons in a recently proposed model of the GnRH pulse generator (Navarro et al., 2009). Kisspeptin neurons in the human can influence $\mathrm{GnRH}$ neurons via axo-somatic, axo-dendritic, and axo-axonal communication (Hrabovszky et al., 2010). Our immunohistochemical results revealed dramatic sex differences in the number of kisspeptin-IR cell bodies, the density of kisspeptin-IR fibers, the incidence of kisspeptin-IR contacts on GnRH neurons and the percent degrees of kisspeptin/NKB colocalization in neuronal afferents to GnRH neurons. All these parameters were significantly higher in aged women compared with aged men, which is compatible with a higher kisspeptin-mediated direct excitatory drive on the reproductive axis in postmenopausal women in comparison with aged men.

It remains to be established if developmental exposure to sex steroids contributes to any extent to the sexual dimorphism of the hypothalamic kisspeptin system. Such organizational effects exist in the ARC of the sheep which contains higher numbers of kisspeptin neurons in females vs. males (Cheng et al., 2010). Most measurable parameters of the sexual dimorphism we report in the present study may be explained by the increased expression of kisspeptin mRNA and the increased number of neurons expressing kisspeptin in women after menopause (Rometo et al., 2007). Similarly, the different incidence of kisspeptin-IR neuronal contacts on GnRH cells and the different colocalization percentages in this inputs between the two sexes may also reflect a different level 
of biosynthesis which may cause subthreshold levels of kisspeptin in a subset of kisspeptin axons, in particular, in males. It requires clarification if the sex difference in the number of kisspeptin-IR neuronal appositions onto GnRH neurons reflects the numerical difference in synaptic inputs or the lower detectability of kisspeptin in a subset of kisspeptin/NKB afferent axons in aged men. The former hypothesis gains support from the observation that the number of excitatory and inhibitory synapses in the ARC can be dynamically regulated by sex steroids (Parducz et al., 2002; Csakvari et al., 2007). The second possibility would be compatible with high levels of kisspeptin immunoreactivity in postmenopausal females which coincided with a higher percentage of NKB-IR contacts that contained kisspeptin in our postmenopausal female samples. Our immunohistochemical observation that the kisspeptinIR innervation of human GnRH neurons is heavier in women is in accordance with the previous findings in mice which revealed a higher percentage of $\mathrm{GnRH}$ neurons that received kisspeptin-IR afferent contacts in the rostral preoptic area of females (Clarkson and Herbison, 2006).

Future studies addressing sex differences between young female and male individuals will be critically important to interpret some observations of the present study. Because kisspeptin and NKB neurons in both young men and women (for most of the menstrual cycle) are under negative sex steroid feedback, their putative sex difference may reflect organizational effects of sex steroids during early development, rather than the different activational effects of the actual sex steroid exposure. Also, it will be similarly important to identify age effects by comparing staining patterns of young to aged subjects of the same sex. Unfortunately, histological samples for such comparative immunohistochemical analyses are currently unavailable in our laboratories.

\section{SEX DIFFERENCES IN PREPRONKB IMMUNOREACTIVITY}

Similarly to kisspeptins, NKB also acts upstream from the $\mathrm{GnRH}$ neuron. In rats, NKB might directly influence $\mathrm{GnRH}$ secretion from the hypothalamic median eminence where GnRH-IR axons are apposed to NKB-IR axons (Krajewski et al., 2005; Ciofi et al., 2006) and express NK3 (Krajewski et al., 2005). Our present study revealed frequent axo-dendritic and axo-somatic contacts between preproNKB-IR axons and GnRH neurons of the human. It requires clarification if NKB can postsynaptically influence GnRH secretion at these contact sites, given that NK3-IR or NK3 mRNA has not been detected in a majority of the cell bodies of GnRH neurons, in rats (Krajewski et al., 2005), ewe (Amstalden et al., 2010), and mice (Navarro et al., 2011). A more likely site of NKB action is on other NKB synthesizing neurons of the ARC/Inf which express NK3 and establish frequent contacts with one another (Burke et al., 2006; Navarro et al., 2009; Amstalden et al., 2010). A recent model of the GnRH pulse generator proposed an intranuclear interplay between three colocalized neuropeptides, kisspeptins, NKB, and dynorphins, which uses NK3 and the dynorphin receptor KOR, but not the kisspeptin receptor (Navarro et al., 2009). Our present study only revealed a significant sex difference in the incidence of prepoNKB-IR cell bodies but not in the density of preproNKBIR fibers and inputs to GnRH neurons. We have to note that sex differences of NKB immunoreactivity were relatively subtle, in comparison with the robust sexual dimorphism of kisspeptin immunoreactivity. If NKB subserves basic mechanisms of pulsatility in the Inf, the NKB-dependent signaling appears to be relatively well-preserved in aged males as well as females. On the other hand, the existing sex differences of the NKB system may be physiologically important in the generation of the different pulsatility patterns between aged males and females.

As we also discussed for kisspeptin, sex differences in preproNKB immunoreactivity can either be partly or entirely due to the different sex steroid exposure of preproNKB neurons in aged males and females. Notably, NKB neurons of the rat (Burke et al., 2006) and the sheep (Goubillon et al., 2000) contain estrogen receptor- $\alpha$ and estrogen treatment reduces preproNKB mRNA expression in the ARC of the rat (Danzer et al., 1999), mouse (Dellovade and Merchenthaler, 2004), sheep (Pillon et al., 2003), and monkeys (Abel et al., 1999). Long-term, but not shortterm, ovariectomy also increased preproNKB mRNA expression in the ARC of monkeys, similarly to the postmenopausal increase observed in old females (Eghlidi et al., 2010).

Our results that preproNKB-IR neurons outnumbered kisspeptin-IR neurons by $120 \%$ in aged males suggest that many NKB neurons do not synthesize detectable amounts of kisspeptins. We have also observed many single-labeled kisspeptin-IR and preproNKB-IR axons in the Inf, which serves as further support for a substantial amount of segregation of kisspeptin and NKB synthesis in the human Inf. These observations are in contrast with the high degree of match between these neuropeptides in sheep (Goodman et al., 2007) and rodents (Navarro et al., 2009) and also indicate that the presence of the other putative neuromessengers of the $\mathrm{GnRH}$ pulse generator in kisspeptin and $\mathrm{NKB}$ neurons of the human Inf need to be carefully readdressed to reveal potential species differences. Future colocalization experiments will be required to establish the putative coexpression of dynorphins, NK3, and the dynorphin receptor KOR in human kisspeptin and NKB neurons. It is worth of note in this context that although prodynorphin expression has been detected in hypertrophied neurons in the Inf of postmenopausal women with in situ hybridization (Rometo and Rance, 2008) and in the ARC of monkeys with real-time PCR (Eghlidi et al., 2010), our preliminary immunohistochemical studies found little evidence for dynorphin A and dynorphin B immunoreactivities in the Inf of post mortem tissue samples. The regulation of prodynorphin expression in the ARC/Inf of different species is also somewhat controversial. The number of neurons expressing prodynorphin was reduced in postmenopausal women (Rometo and Rance, 2008), showed no significant postmenopausal change in monkeys (Eghlidi et al., 2010) and was upregulated in the absence of sex steroids (in parallel with KISS1 and preproNKB gene expression) in mice (Navarro et al., 2009).

\section{THE MAIN OBSERVATIONS OF OUR PRESENT STUDY ARE SUMMARIZED BELOW}

(i) KP- and NKB-immunoreactive (IR) cell bodies of the Inf are larger in aged human females than in males, which reflect a postmenopausal loss of estrogen negative feedback.

(ii) The number of KP-IR cell bodies, the density of KP-IR fibers, and the incidence of their contacts on GnRH neurons are much higher in aged women compared with men. 
(iii) The number of NKB cell bodies is also only slightly higher in the Inf of women compared with men, whereas there is no significant sexual dimorphism in the regional density of $\mathrm{NKB}$ fibers and the incidence of their appositions onto $\mathrm{GnRH}$ cells.

(iv) The incidences of NKB-IR cell bodies, fibers, and appositions onto GnRH neurons exceed several-fold those of KP-IR elements in men. More NKB than KP inputs to GnRH cells are also present in women, whereas NKB and $\mathrm{KP}$ immunoreactivities do not differ in the other parameters.

(v) Only partial overlap exists between KP-IR and NKB-IR axons. $\mathrm{KP}$ is present in a higher percentage of NKB-IR afferents to GnRH neurons in women (31\%) compared with men (9\%)

\section{REFERENCES}

Abel, T. W., and Rance, N. E. (2000). Stereologic study of the hypothalamic infundibular nucleus in young and older women. J. Comp. Neurol. 424, 679-688.

Abel, T. W., Voytko, M. L., and Rance, N. E. (1999). The effects of hormone replacement therapy on hypothalamic neuropeptide gene expression in a primate model of menopause. J. Clin. Endocrinol. Metab. 84, 2111-2118.

Adachi, S., Yamada, S., Takatsu, Y., Matsui, H., Kinoshita, M., Takase, K., Sugiura, H., Ohtaki, T., Matsumoto, H., Uenoyama, Y., Tsukamura, H., Inoue, K., and Maeda, K. (2007). Involvement of anteroventral periventricular metastin/kisspeptin neurons in estrogen positive feedback action on luteinizing hormone release in female rats. J. Reprod. Dev. 53, 367-378.

Amstalden, M., Coolen, L. M., Hemmerle, A. M., Billings, H. J., Connors, J. M., Goodman, R. L., and Lehman, M. N. (2010). Neurokinin 3 receptor immunoreactivity in the septal region, preoptic area and hypothalamus of the female sheep: colocalisation in neurokinin B cells of the arcuate nucleus but not in gonadotrophin-releasing hormone neurones. J. Neuroendocrinol. 22, $1-12$.

Ansel, L., Bolborea, M., Bentsen, A. H., Klosen, P., Mikkelsen, J. D., and Simonneaux, V. (2010). Differential regulation of kiss 1 expression by melatonin and gonadal hormones in male and female Syrian hamsters. J. Biol. Rhythms 25, 81-91.

Araujo, A. B., and Wittert, G. A. (2011). Endocrinology of the aging male. Best Pract. Res. Clin. Endocrinol. Metab. 25, 303-319.

Burke, M. C., Letts, P. A., Krajewski, S. J., and Rance, N. E. (2006). Coexpression of dynorphin and neurokinin B immunoreactivity in the rat hypothalamus: morphologic evidence of interrelated function within the arcuate nucleus. J. Comp. Neurol. 498, 712-726.

Caraty, A., Fabre-Nys, C., Delaleu, B., Locatelli, A., Bruneau, G., Karsch, F. J., and Herbison, A. (1998). Evidence that the mediobasal hypothalamus is the primary site of action of estradiol in inducing the preovulatory gonadotropin releasing hormone surge in the ewe. Endocrinology 139, 1752-1760. manabhan, V., Goodman, R. L., and Lehman, M. N. (2010). The kisspeptin/neurokinin B/dynorphin (KNDy). Cell population of the arcuate nucleus: sex differences and effects of prenatal testosterone in sheep. Endocrinology 151, 301-311.

Christian, C. A., and Moenter, S. M. (2010). The neurobiology of preovulatory and estradiol-induced gonadotropin-releasing hormone surges. Endocr. Rev. 31, 544-577.

Ciofi, P., Leroy, D., and Tramu, G. (2006). Sexual dimorphism in the organization of the rat hypothalamic infundibular area. Neuroscience 141, 1731-1745.

Clarkson, J., d'Anglemont de Tassigny, X., Colledge, W. H., Caraty, A., and Herbison, A. E. (2009). Distribution of kisspeptin neurones in the adult female mouse brain. J. Neuroendocrinol. 21, 673-682.

Clarkson, J., d'Anglemont de Tassigny, X., Moreno, A. S., Colledge, W. H., and Herbison, A. E. (2008). Kisspeptin-GPR54 signaling is essential for preovulatory gonadotropin-releasing hormone neuron activation and the luteinizing hormone surge. J. Neurosci. 28, 8691-8697.

Clarkson, J., and Herbison, A. E. (2006). Postnatal development of kisspeptin neurons in mouse hypothalamus; sexual dimorphism and projections to gonadotropin-releasing
Cheng, G., Coolen, L. M., Pad-

and the percentage of KP-IR contacts co-containing NKB is also higher in females $(26 \%)$ than in males $(10 \%)$.

\section{ACKNOWLEDGMENTS}

The research leading to these results has received funding from the National Science Foundation of Hungary (OTKA K69127, K83710 and T73002), the Hungarian Health Research Council Fund (ETT 122/2009) and the European Community's Seventh Framework Programme (FP7/2007-2013) under grant agreement no. 245009. We thank Dr. R. A. Benoit for the kind donation of the LR1 GnRH antibodies, Dr. S. M. Moenter for providing us the GnRH-GFP transgenic mice and Hajni Bekó for the technical assistance. WSD is funded by an NIHR Career Development Fellowship.

hormone neurons. Endocrinology 147, 5817-5825.

Csakvari, E., Hoyk, Z., Gyenes, A., Garcia-Ovejero, D., Garcia-Segura, L. M., and Parducz, A. (2007). Fluctuation of synapse density in the arcuate nucleus during the estrous cycle. Neuroscience 144, 1288-1292.

Danzer, S. C., Price, R. O., McMullen, N. T., and Rance, N. E. (1999). Sex steroid modulation of neurokinin $B$ gene expression in the arcuate nucleus of adult male rats. Brain Res. Mol. Brain Res. 66, 200-204.

de Roux, N., Genin, E., Carel, J. C., Matsuda, F., Chaussain, J. L., and Milgrom, E. (2003). Hypogonadotropic hypogonadism due to loss of function of the KiSS1-derived peptide receptor GPR54. Proc. Natl. Acad. Sci. U.S.A. 100, 10972-10976.

Decourt, C., Tillet, Y., Caraty, A. Franceschini, I., and Briant, C. (2008). Kisspeptin immunoreactive neurons in the equine hypothalamus Interactions with GnRH neuronal system. J. Chem. Neuroanat. 36, 131-137.

Dellovade, T. L., and Merchenthaler, I. (2004). Estrogen regulation of neurokinin $\mathrm{B}$ gene expression in the mouse arcuate nucleus is mediated by estrogen receptor alpha. Endocrinology 145, 736-742.

Desroziers, E., Mikkelsen, J., Simonneaux, V., Keller, M., Tillet, Y., Caraty, A., and Franceschini, I. (2010). Mapping of kisspeptin fibres in the brain of the pro-oestrous rat. J. Neuroendocrinol. 22, 1101-1112.

Dhillo, W. S., Chaudhri, O. B., Patterson, M., Thompson, E. L., Murphy, K. G., Badman, M. K., McGowan, B. M., Amber, V., Patel, S., Ghatei, M. A., and Bloom, S. R. (2005). Kisspeptin54 stimulates the hypothalamicpituitary gonadal axis in human males. J. Clin. Endocrinol. Metab. 90, 6609-6615.

Dhillo, W. S., Chaudhri, O. B., Thompson, E. L., Murphy, K. G., Patterson, M., Ramachandran, R., Nijher, G. K.,
Amber, V., Kokkinos, A., Donaldson, M., Ghatei, M. A., and Bloom, S. R. (2007). Kisspeptin-54 stimulates gonadotropin release most potently during the preovulatory phase of the menstrual cycle in women. J. Clin. Endocrinol. Metab. 92, 3958-3966.

Dumalska, I., Wu, M., Morozova, E., Liu, R., van den Pol, A., and Alreja, M. (2008). Excitatory effects of the puberty-initiating peptide kisspeptin and group I metabotropic glutamate receptor agonists differentiate two distinct subpopulations of gonadotropin-releasing hormone neurons. J. Neurosci. 28, 8003-8013.

Eghlidi, D. H., Haley, G. E., Noriega, N. C., Kohama, S. G., and Urbanski, H. F. (2010). Influence of age and 17beta-estradiol on kisspeptin, neurokinin $\mathrm{B}$, and prodynorphin gene expression in the arcuatemedian eminence of female rhesus macaques. Endocrinology 151, 3783-3794.

Estrada, K. M., Clay, C. M., Pompolo, S., Smith, J. T., and Clarke, I. J. (2006). Elevated KiSS-1 expression in the arcuate nucleus prior to the cyclic preovulatory gonadotrophinreleasing hormone/lutenising hormone surge in the ewe suggests a stimulatory role for kisspeptin in oestrogen-positive feedback. J. Neuroendocrinol. 18, 806-809.

Franceschini, I., Lomet, D., Cateau, M., Delsol, G., Tillet, Y., and Caraty, A. (2006). Kisspeptin immunoreactive cells of the ovine preoptic area and arcuate nucleus co-express estrogen receptor alpha. Neurosci. Lett. 401, 225-230.

Goodman, R. L., Lehman, M. N., Smith, J. T., Coolen, L. M., de Oliveira, C. V., Jafarzadehshirazi, M. R., Pereira, A., Iqbal, J., Caraty, A., Ciofi, P., and Clarke, I. J. (2007). Kisspeptin neurons in the arcuate nucleus of the ewe express both dynorphin A and neurokinin B. Endocrinology 148, 5752-5760 
Gottsch, M. L., Cunningham, M. J., Smith, J. T., Popa, S. M., Acohido, B. V., Crowley, W. F., Seminara, S., Clifton, D. K., and Steiner, R. A. (2004). A role for kisspeptins in the regulation of gonadotropin secretion in the mouse. Endocrinology 145, 4073-4077.

Goubillon, M. L., Forsdike, R. A., Robinson, J. E., Ciofi, P., Caraty, A., and Herbison, A. E. (2000). Identification of neurokinin B-expressing neurons as an highly estrogenreceptive, sexually dimorphic cell group in the ovine arcuate nucleus. Endocrinology 141, 4218-4225.

Greives, T. J., Mason, A. O., Scotti, M. A., Levine, J., Ketterson, E. D., Kriegsfeld, L. J., and Demas, G. E. (2007). Environmental control of kisspeptin: implications for seasonal reproduction. Endocrinology 148, 1158-1166.

Guran, T., Tolhurst, G., Bereket, A., Rocha, N., Porter, K., Turan, S., Gribble, F. M., Kotan, L. D., Akcay, T., Atay, Z., Canan, H., Serin, A., O’Rahilly, S., Reimann, F., Semple, R. K., and Topaloglu, A. K. (2009). Hypogonadotropic hypogonadism due to a novel missense mutation in the first extracellular loop of the neurokinin B receptor. J. Clin. Endocrinol. Metab. 94, 3633-3639.

Han, S. K., Gottsch, M. L., Lee, K. J., Popa, S. M., Smith, J. T., Jakawich, S. K., Clifton, D. K., Steiner, R. A., and Herbison, A. E. (2005). Activation of gonadotropin-releasing hormone neurons by kisspeptin as a neuroendocrine switch for the onset of puberty. J. Neurosci. 25, 11349-11356.

Herbison, A. E. (2008). Estrogen positive feedback to gonadotropinreleasing hormone $(\mathrm{GnRH})$. Neurons in the rodent: the case for the rostral periventricular area of the third ventricle (RP3V). Brain Res. Rev. 57, 277-287.

Hess, D. L., Wilkins, R. H., Moossy, J., Chang, J. L., Plant, T. M., McCormack, J. T., Nakai, Y., and Knobil, E. (1977). Estrogen-induced gonadotropin surges in decerebrated female rhesus monkeys with medial basal hypothalamic peninsulae. Endocrinology 101, 1264-1271.

Hrabovszky, E., Ciofi, P., Vida, B., Horvath, M. C., Keller, E., Caraty, A., Bloom, S. R., Ghatei, M. A., Dhillo, W. S., Liposits, Z., and Kallo, I. (2010). The kisspeptin system of the human hypothalamus: sexual dimorphism and relationship with gonadotropin-releasing hormone and neurokinin $B$ neurons. Eur. J. Neurosci. 31, 1984-1998.
Hrabovszky, E., Kallo, I., Szlavik, N., Keller, E., Merchenthaler, I., and Liposits, Z. (2007). Gonadotropinreleasing hormone neurons express estrogen receptor-beta. J. Clin. Endocrinol. Metab. 92, 2827-2830.

Irwig, M. S., Fraley, G. S., Smith, J. T., Acohido, B. V., Popa, S. M., Cunningham, M. J., Gottsch, M. L., Clifton, D. K., and Steiner, R. A. (2004). Kisspeptin activation of gonadotropin releasing hormone neurons and regulation of KiSS-1 mRNA in the male rat. Neuroendocrinology 80, 264-272.

Jayasena, C. N., Nijher, G. M. K., Comninos, A. N., Abbara, A., Januszewki, A., Vaal, M. L., Sriskandarajah, L., Murphy, K. G., Farzad, Z., Ghatei, M. A., Bloom, S. R., and Dhillo, W. S. (2011). The effects of kisspeptin10 on reproductive hormone release show sexual dimorphism in humans. J. Clin. Endocrinol. Metab. doi: 10.1210/jc.2011-1408. [Epub ahead of print].

Kauffman, A. S. (2009). Sexual differentiation and the Kiss1 system: hormonal and developmental considerations. Peptides 30, 83-93.

Kauffman, A. S., Gottsch, M. L., Roa, J., Byquist, A. C., Crown, A., Clifton, D. K., Hoffman, G. E., Steiner, R. A., and Tena-Sempere, M. (2007). Sexual differentiation of Kiss1 gene expression in the brain of the rat. Endocrinology 148, 1774-1783.

Kim, W., Jessen, H. M., Auger, A. P., and Terasawa, E. (2009). Postmenopausal increase in KiSS1, GPR54, and luteinizing hormone releasing hormone (LHRH-1) mRNA in the basal hypothalamus of female rhesus monkeys. Peptides 30, 103-110.

Kinoshita, M., Tsukamura, H., Adachi, S., Matsui, H., Uenoyama, Y., Iwata, K., Yamada, S., Inoue, K., Ohtaki, T., Matsumoto, H., and Maeda, K. (2005). Involvement of central metastin in the regulation of preovulatory luteinizing hormone surge and estrous cyclicity in female rats. Endocrinology 146, 4431-4436.

Knobil, E. (1980). The neuroendocrine control of the menstrual cycle. Recent Prog. Horm. Res. 36, 53-88.

Krajewski, S. J., Anderson, M. J., IlesShih, L., Chen, K. J., Urbanski, H. F., and Rance, N. E. (2005). Morphologic evidence that neurokinin B modulates gonadotropinreleasing hormone secretion via neurokinin 3 receptors in the rat median eminence. J. Comp. Neurol. 489, 372-386.

Krey, L. C., Butler, W. R., and Knobil, E. (1975). Surgical disconnection of the medial basal hypothalamus and pituitary function in the rhesus monkey. I. Gonadotropin secretion. Endocrinology 96, 1073-1087.

Lehman, M. N., Coolen, L. M. and Goodman, R. L. (2010a). Minireview: kisspeptin/neurokinin B/dynorphin (KNDy). Cells of the arcuate nucleus: a central node in the control of gonadotropin-releasing hormone secretion. Endocrinology 151, 3479-3489.

Lehman, M. N., Merkley, C. M., Coolen, L. M., and Goodman, R. L. (2010b). Anatomy of the kisspeptin neural network in mammals. Brain Res. 1364, 90-102.

Liposits, Z., Setalo, G., and Flerko, B. (1984). Application of the silver-gold intensified 3,3'diaminobenzidine chromogen to the light and electron microscopic detection of the luteinizing hormone-releasing hormone system of the rat brain. Neuroscience 13 513-525.

Magee, C., Foradori, C. D., Bruemmer J. E., Arreguin-Arevalo, J. A., McCue, P. M., Handa, R. J., Squires, E. L., and Clay, C. M. (2009). Biological and anatomical evidence for kisspeptin regulation of the hypothalamicpituitary-gonadal axis of estrous horse mares. Endocrinology 150, 2813-2821.

Mason, A. O., Greives, T. J., Scotti, M. A., Levine, J., Frommeyer, S., Ketterson, E. D., Demas, G. E., and Kriegsfeld, L. J. (2007). Suppression of kisspeptin expression and gonadotropic axis sensitivity following exposure to inhibitory day lengths in female Siberian hamsters. Horm. Behav. 52, 492-498.

Matsui, H., Takatsu, Y., Kumano, S., Matsumoto, H., and Ohtaki, T. (2004). Peripheral administration of metastin induces marked gonadotropin release and ovulation in the rat. Biochem. Biophys. Res Commun. 320, 383-388.

Messager, S., Chatzidaki, E. E., Ma, D., Hendrick, A. G., Zahn, D., Dixon, J. Thresher, R. R., Malinge, I., Lomet, D., Carlton, M. B., Colledge, W. H., Caraty, A., and Aparicio, S. A. (2005). Kisspeptin directly stimulates gonadotropin-releasing hormone release via $\mathrm{G}$ protein-coupled receptor 54. Proc. Natl. Acad. Sci. U.S.A. 102, 1761-1766.

Mihaly, E., Fekete, C., Lechan, R. M., and Liposits, Z. (2002). Corticotropinreleasing hormone-synthesizing neurons of the human hypothalamus receive neuropeptide Y-immunoreactive innervation from neurons residing primarily outside the infundibular nucleus. $J$. Comp. Neurol. 446, 235-243.
Moenter, S. M., Chu, Z., and Christian, C. A. (2009). Neurobiological mechanisms underlying oestradiol negative and positive feedback regulation of gonadotrophin-releasing hormone neurones. J. Neuroendocrinol. 21, 327-333.

Navarro, V. M., Gottsch, M. L., Chavkin, C., Okamura, H., Clifton, D. K., and Steiner, R. A. (2009). Regulation of gonadotropinreleasing hormone secretion by kisspeptin/dynorphin/neurokinin

$\mathrm{B}$ neurons in the arcuate nucleus of the mouse. J. Neurosci. 29, 11859-11866.

Navarro, V. M., Gottsch, M. L., Wu, M., Garcia-Galiano, D., Hobbs, S. J., Bosch, M. A., Pinilla, L., Clifton, D. K., Dearth, A., Ronnekleiv, O. K., Braun, R. E., Palmiter, R. D., Tena-Sempere, M., Alreja, M., and Steiner, R. A. (2011). Regulation of NKB pathways and their roles in the control of Kiss1 neurons in the arcuate nucleus of the male mouse. Endocrinology 152, 4265-4275.

Ohkura, S., Takase, K., Matsuyama, S., Mogi, K., Ichimaru, T., Wakabayashi, Y., Uenoyama, Y., Mori, Y., Steiner, R. A., Tsukamura, H., Maeda, K. I., and Okamura, H. (2009). Gonadotrophinreleasing hormone pulse generator activity in the hypothalamus of the goat. J. Neuroendocrinol. 21, 813-821.

Parducz, A., Hoyk, Z., Kis, Z., and Garcia-Segura, L. M. (2002). Hormonal enhancement of neuronal firing is linked to structural remodelling of excitatory and inhibitory synapses. Eur. J. Neurosci. 16 , 665-670.

Pielecka-Fortuna, J., Chu, Z., and Moenter, S. M. (2008). Kisspeptin acts directly and indirectly to increase gonadotropin-releasing hormone neuron activity and its effects are modulated by estradiol. Endocrinology 149, 1979-1986.

Pillon, D., Caraty, A., Fabre-Nys, C., and Bruneau, G. (2003). Short-term effect of oestradiol on neurokinin $B$ mRNA expression in the infundibular nucleus of ewes. I. Neuroendocrinol. 15, 749-753.

Ramaswamy, S., Guerriero, K. A., Gibbs, R. B., and Plant, T. M. (2008). Structural interactions between kisspeptin and GnRH neurons in the mediobasal hypothalamus of the male rhesus monkey (Macaca mulatta). As revealed by double immunofluorescence and confocal microscopy. Endocrinology 149, 4387-4395. 
Ramaswamy, S., Seminara, S. B., Ali, B., Ciofi, P., Amin, N. A., and Plant, T. M. (2010). Neurokinin B stimulates $\mathrm{GnRH}$ release in the male monkey (Macaca mulatta) and is colocalized with kisspeptin in the arcuate nucleus. Endocrinology 151, 4494-4503.

Rance, N. E. (2009). Menopause and the human hypothalamus: evidence for the role of kisspeptin/neurokinin B neurons in the regulation of estrogen negative feedback. Peptides 30, 111-122.

Rance, N. E., and Bruce, T. R. (1994). Neurokinin B gene expression is increased in the arcuate nucleus of ovariectomized rats. Neuroendocrinology 60 , 337-345.

Rance, N. E., McMullen, N. T., Smialek, J. E., Price, D. L., and Young, W. S. III. (1990). Postmenopausal hypertrophy of neurons expressing the estrogen receptor gene in the human hypothalamus. J. Clin. Endocrinol. Metab. 71, 79-85.

Rance, N. E., Uswandi, S. V., and McMullen, N. T. (1993). Neuronal hypertrophy in the hypothalamus of older men. Neurobiol. Aging 14, 337-342.

Rance, N. E., and Young, W. S. III. (1991). Hypertrophy and increased gene expression of neurons containing neurokinin-B and substance-P messenger ribonucleic acids in the hypothalami of postmenopausal women. Endocrinology 128, 2239-2247.

Revel, F. G., Saboureau, M., MassonPevet, M., Pevet, P., Mikkelsen, J. D., and Simonneaux, V. (2006). Kisspeptin mediates the photoperiodic control of reproduction in hamsters. Curr. Biol. 16, 1730-1735.

Rometo, A. M., Krajewski, S. J., Voytko, M. L., and Rance, N. E. (2007). Hypertrophy and increased kisspeptin gene expression in the hypothalamic infundibular nucleus of postmenopausal women and ovariectomized monkeys. J. Clin. Endocrinol. Metab. 92, 2744-2750.

Rometo, A. M., and Rance, N. E. (2008). Changes in prodynorphin gene expression and neuronal morphology in the hypothalamus of postmenopausal women. J. Neuroendocrinol. 20, 1376-1381.
Seminara, S. B., Messager, S., Chatzidaki, E. E., Thresher, R. R., Acierno, J. S. Jr., Shagoury, J. K., Bo-Abbas, Y., Kuohung, W., Schwinof, K. M., Hendrick, A. G., Zahn, D., Dixon, J., Kaiser, U. B., Slaugenhaupt, S. A., Gusella, J. F., O'Rahilly, S., Carlton, M. B., Crowley, W. F. Jr., Aparicio, S. A., and Colledge, W. H. (2003). The GPR54 gene as a regulator of puberty. N. Engl. J. Med. 349, 1614-1627.

Semple, R. K., Achermann, J. C., Ellery, J., Farooqi, I. S., Karet, F. E., Stanhope, R. G., O'Rahilly, S., and Aparicio, S. A. (2005). Two novel missense mutations in $\mathrm{g}$ protein-coupled receptor 54 in a patient with hypogonadotropic hypogonadism. J. Clin. Endocrinol. Metab. 90, 1849-1855.

Shahab, M., Mastronardi, C., Seminara, S. B., Crowley, W. F., Ojeda, S. R., and Plant, T. M. (2005). Increased hypothalamic GPR54 signaling: a potential mechanism for initiation of puberty in primates. Proc. Natl. Acad. Sci. U.S.A. 102, 2129-2134.

Sheehan, H. L. (1967). Variations in the subventricular nucleus. J. Pathol. Bacteriol. 94, 409-416.

Sheehan, H. L., and Kovacs, K. (1966). The subventricular nucleus of the human hypothalamus. Brain 89, 589-614.

Smith, J. T., Clay, C. M., Caraty, A., and Clarke, I. J. (2007). KiSS-1 messenger ribonucleic acid expression in the hypothalamus of the ewe is regulated by sex steroids and season. Endocrinology 148, 1150-1157.

Smith, J. T., Clifton, D. K., and Steiner, R. A. (2006a). Regulation of the neuroendocrine reproductive axis by kisspeptin-GPR54 signaling. Reproduction 131, 623-630.

Smith, J. T., Popa, S. M., Clifton, D. K., Hoffman, G. E., and Steiner, R. A. (2006b). Kiss1 neurons in the forebrain as central processors for generating the preovulatory luteinizing hormone surge. J. Neurosci. 26, 6687-6694.

Smith, J. T., Coolen, L. M., Kriegsfeld, L. J., Sari, I. P., Jaafarzadehshirazi, M. R., Maltby, M., Bateman, K., Goodman, R. L., Tilbrook, A. J., Ubuka, T., Bentley, G. E., Clarke, I. J., and Lehman, M. N. (2008). Variation in kisspeptin and RFamiderelated peptide (RFRP) expression and terminal connections to gonadotropin-releasing hormone neurons in the brain: a novel medium for seasonal breeding in the sheep. Endocrinology 149, 5770-5782.

Smith, J. T., Cunningham, M. J., Rissman, E. F., Clifton, D. K., and Steiner, R. A. (2005a). Regulation of Kiss1 gene expression in the brain of the female mouse. Endocrinology 146, 3686-3692.

Smith, J. T., Dungan, H. M., Stoll, E. A., Gottsch, M. L., Braun, R. E., Eacker, S. M., Clifton, D. K., and Steiner, R. A. (2005b). Differential regulation of KiSS-1 mRNA expression by sex steroids in the brain of the male mouse. Endocrinology 146, 2976-2984.

Smith, J. T., Li, Q., Pereira, A., and Clarke, I. J. (2009). Kisspeptin neurons in the ovine arcuate nucleus and preoptic area are involved in the preovulatory luteinizing hormone surge. Endocrinology 150, 5530-5538.

Smith, J. T., Shahab, M., Pereira, A., Pau, K. Y., and Clarke, I. J. (2010). Hypothalamic expression of KISS1 and gonadotropin inhibitory hormone genes during the menstrual cycle of a non-human primate. Biol. Reprod. 83, 568-577.

Suter, K. J., Song, W. J., Sampson, T. L., Wuarin, J. P., Saunders, J. T., Dudek, F. E., and Moenter, S. M. (2000). Genetic targeting of green fluorescent protein to gonadotropinreleasing hormone neurons: characterization of whole-cell electrophysiological properties and morphology. Endocrinology 141, 412-419.

Takase, K., Uenoyama, Y., Inoue, N. Matsui, H., Yamada, S., Shimizu, M. Homma, T., Tomikawa, J., Kanda, S., Matsumoto, H., Oka, Y., Tsukamura, H., and Maeda, K. I. (2009). Possible role of oestrogen in pubertal increase of Kiss1/kisspeptin expression in discrete hypothalamic areas of female rats. J. Neuroendocrinol. 21, 527-537.

Tilbrook, A. J., and Clarke, I. J. (2001). Negative feedback regulation of the secretion and actions of gonadotropin-releasing hormone in males. Biol. Reprod. 64, 735-742.

Topaloglu, A. K., Reimann, F., Guclu, M. Yalin, A. S., Kotan, L. D., Porter, K. M., Serin, A., Mungan, N. O., Cook, J. R., Ozbek, M. N., Imamoglu, S.,
Akalin, N. S., Yuksel, B., O’Rahilly, S., and Semple, R. K. (2009). TAC3 and TACR3 mutations in familial hypogonadotropic hypogonadism reveal a key role for Neurokinin B in the central control of reproduction. Nat. Genet. 41, 354-358.

Veldhuis, J. D., Takahashi, P. Y., Keenan, D. M., Liu, P. Y., Mielke, K. L., and Weist, S. M. (2010). Age disrupts androgen receptor-modulated negative feedback in the gonadal axis in healthy men. Am. J. Physiol. Endocrinol. Metab. 299, E675-E682.

Wakabayashi, Y., Nakada, T., Murata, K. Ohkura, S., Mogi, K., Navarro, V. M., Clifton, D. K., Mori, Y., Tsukamura, H., Maeda, K., Steiner, R. A., and Okamura, H. (2010). Neurokinin B and dynorphin $\mathrm{A}$ in kisspeptin neurons of the arcuate nucleus participate in generation of periodic oscillation of neural activity driving pulsatile gonadotropin-releasing hormone secretion in the goat. $\mathrm{J}$. $\mathrm{Neu}$ rosci. 30, 3124-3132.

Conflict of Interest Statement: The authors declare that the research was conducted in the absence of any commercial or financial relationships that could be construed as a potential conflict of interest.

Received: 29 September 2011; paper pending published: 17 October 2011; accepted: 08 November 2011; published online: 01 December 2011.

Citation: Hrabovszky E, Molnár CS, Sipos MT, Vida B, Ciofi P, Borsay BA, Sarkadi L, Herczeg L, Bloom SR, Ghatei MA, Dhillo WS, Kalló I and Liposits $Z$ (2011) Sexual dimorphism of kisspeptin and neurokinin B immunoreactive neurons in the infundibular nucleus of aged men and women. Front. Endocrin. 2:80. doi: 10.3389/fendo.2011.00080

This article was submitted to Frontiers in Genomic Endocrinology, a specialty of Frontiers in Endocrinology.

Copyright (c) 2011 Hrabovszky, Molnár, Sipos, Vida, Ciofi, Borsay, Sarkadi, Herczeg, Bloom, Ghatei, Dhillo, Kalló and Liposits. This is an open-access article distributed under the terms of the Creative Commons Attribution Non Commercial License, which permits noncommercial use, distribution, and reproduction in other forums, provided the original authors and source are credited. 